\title{
PROTEÇÃO DOS PARTICULARES E CENSURA PRIVADA: A JURISPRUDÊNCIA CONSTITUCIONAL SOBRE OS LIMITES À LIBERDADE DE EXPRESSÃO
}

\author{
PROTECTION OF INDIVIDUALS AND PRIVATE CENSORSHIP: \\ THE JUDICIAL REVIEW ON THE LIMITS OF FREEDOM OF SPEECH
}

\section{LA PROTECCIÓN DE LOS PARTICULARES Y LA CENSURA PRIVADA: LA JURISPRUDENCIA CONSTITUCIONAL SOBRE LOS LIIMITES A LA LIBERTAD DE EXPRESIÓN}

\author{
ELDEN BORGES SOUZA \\ https://orcid.org/0000-0002-1089-8905 / http://lattes.cnpq.br/0097457768160631 / elden.borges@gmail.com \\ Universidade Federal do Pará - UFPA \\ Belém, PA, Brasil.
}

Victor SALEs PinHeiro http://orcid.org/0000-0003-1908-9618 / http://lattes.cnpq.br/0416222855469529 / vvspinheiro@yahoo.com.br Universidade Federal do Pará - UFPA

Belém, PA, Brasil.

\begin{abstract}
RESUMO
Um dos princípios fundamentais das democracias contemporâneas é a liberdade de expressão. A pluralidade política, religiosa e de pensamento que marcou o desenvolvimento do Ocidente fez com que a afirmação da democracia viesse, como regra, conjugada à afirmação de algumas liberdades fundamentais. No entanto, a liberdade de pensamento também é relevante para as relações entre particulares. Tanto para que se identifiquem os casos em que se aplica, como para definir seus limites. Afinal, normalmente essas limitações são vistas como potencial censura. No entanto, tal limitação é necessária, pois, como qualquer direito fundamental, a liberdade de expressão não pode servir de guarida a atitudes que violem outros interesses constitucionalmente previstos. Neste sentido, o objetivo deste trabalho é analisar a jurisprudência do Supremo Tribunal Federal ao ponderar os limites admissíveis à liberdade de expressão, buscando identificar a sistemática utilizada para aplicação dessa liberdade às relações entre particulares. A pesquisa analisa alguns casos emblemáticos julgados a partir da promulgação da Constituição Federal de 1988 por meio de uma metodologia bibliográfica e dialética.
\end{abstract}

Palavras-chave: Jurisdição Constitucional; Liberdade de Expressão; Relações Privadas; Supremo Tribunal Federal.

\begin{abstract}
One of the basic principles of contemporary democracies is freedom of speech. The plurality of politics, religion and thought that marked the development of the West made the assertion of democracy as a rule coupled with the affirmation of some fundamental freedoms. However, freedom of speech is also relevant to contractual relationships. Both to identify the cases in which it applies, and to define its limits. After all, these limitations are usually seen as potential censorship. However, such a limitation is necessary because, like any fundamental right, freedom of speech cannot serve as a refuge for attitudes that violate other constitutionally foreseen interests. In this sense, the objective of this work is to analyze the jurisprudence of the Brazilian Supreme Court in considering the admissible limits to freedom of speech, seeking to identify the system used to apply this freedom to contractual relations. The research analyzed some emblematic cases judged from the promulgation of the Brazilian Constitution of 1988 through a bibliographical and dialectical methodology.
\end{abstract}

Keywords: Judicial Review; Freedom of Speech; Contractual relationships; Supreme Court. 


\section{RESUMEN}

Uno de los principios fundamentales de las democracias contemporáneas es la libertad de expresión. La pluralidad política, religiosa y de pensamiento que marcó el desarrollo de Occidente hizo que la afirmación de la democracia viniera, como regla, conjugada a la afirmación de algunas libertades fundamentales. Sin embargo, la libertad de pensamiento también es relevante para las relaciones entre particulares. Tanto para que se identifiquen los casos en que se aplica, como para definir sus límites. Al final, normalmente estas limitaciones se ven como una posible censura. Sin embargo, tal limitación es necesaria, pues, como cualquier derecho fundamental, la libertad de expresión no puede servir de guarida a actitudes que violen otros intereses constitucionalmente previstos. En este sentido, el objetivo de este trabajo es analizar la jurisprudencia de la Suprema Corte Brasileña al ponderar los límites admisibles a la libertad de expresión, buscando identificar la sistemática utilizada para la aplicación de esa libertad a las relaciones entre particulares. La investigación analizó algunos casos emblemáticos juzgados a partir de la promulgación de la Constitución Federal de 1988 por medio de una metodología bibliográfica y dialéctica.

Palabras clave: Jurisdicción Constitucional; Libertad de expresión; Relaciones privadas; Suprema Corte.

\section{SUMÁRIO}

INTRODUÇAO; 1 DEMOCRACIA, LIBERDADE DE EXPRESSÃO, SEUS LIMITES E MÉTODOS DE RESTRIÇÃO; 2 O CASO ELLWANGER E A ABRANGÊNCIA DA LIBERDADE; 3 O CASO DA MANIFESTAÇÃO NA PRAÇA DOS TRÊS PODERES E A PROTEÇÃO DA EFETIVIDADE DA LIBERDADE; 4 O CASO DA LEI DE IMPRENSA E 0 STATUS JURÍDICO DA LIBERDADE; 5 O CASO DA MARCHA DA MACONHA E A PROTEÇÃO DO DISCURSO CRÍTICO AO DIREITO VIGENTE; 6 O CASO DAS BIOGRAFIAS NÃO AUTORIZADAS E A PROTEÇÃO CONTRA A CENSURA PRIVADA; 7 UMA ANÁLISE TRANSVERSAL DA JURISPRUDÊNCIA; CONCLUSÃO; REFERÊNCIAS.

\section{INTRODUÇÃO}

Um dos princípios fundamentais das democracias contemporâneas é a liberdade de expressão. De fato, a pluralidade política, religiosa e de pensamento que marcou o desenvolvimento histórico dos contextos democráticos ocidentais fez com que a afirmação da democracia viesse, como regra, conjugada com a afirmação de algumas liberdades fundamentais. De tais liberdades, sempre ganhou notoriedade a liberdade de expressão do pensamento.

No entanto, a ampla garantia deste direito fundamental acabou acarretando um conflito prático: devemos reconhecer limites a ela? Ou devemos preservá-la de forma ilimitada. Uma vez que não existem direitos absolutos, essa liberdade também não é absoluta, nem superior a outros princípios constitucionais ${ }^{1}$.

Normalmente essas limitações são vistas como potencial censura. No entanto, tal limitação é necessária, pois, como qualquer direito fundamental, a liberdade de expressão não pode servir de guarida a atitudes que violem outros interesses constitucionalmente previstos -

${ }^{1}$ BASTOS, Celso Ribeiro. Hermenêutica e Interpretação Constitucional. 2. ed. São Paulo: IBDC, 1999, p. 103. 
ISSN 1981-3694

(DOI): $10.5902 / 1981369437843$

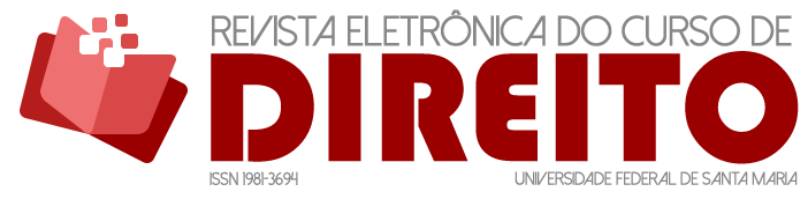

PROTEÇ̃̃O DOS PARTICULARES E CENSURA PRIVADA: A JURISPRUDÊNCIA CONSTITUCIONAL SOBRE OS LIMITES À LIBERDADE DE EXPRESSÃO

ELDEN BORGES SOUZA VICTOR SALES PINHEIRO

como o princípio da não discriminação e os direitos à honra e à imagem. Não obstante, como tal liberdade está intrinsecamente ligada ao desenvolvimento da personalidade e à garantia da democracia, seus limites devem ser estipulados na medida do estritamente necessário.

Dessa forma, a proteção e limitação da liberdade de expressão são questões que não afetam apenas as relações na esfera pública, como também na esfera privada. Por um lado, pois a expressão de alguém é essencial à garantia de sua liberdade e afirmação de sua identidade enquanto sujeito autônomo. Por outro lado, pois tais manifestações podem afetar a esfera de outro particular - exigindo, portanto, uma análise da aplicação dos direitos fundamentais nas relações privadas.

Neste sentido, o objetivo deste trabalho é analisar a concepção jurisprudencial da Suprema Corte brasileira, desde a promulgação da Carta de 1988, nos julgamentos de alguns casos paradigmáticos (hard cases), em que precisou ponderar limites admissíveis à liberdade de expressão, atuando como mediador dos interesses conflitantes, buscando identificar a sistemática utilizada para aplicação dessa liberdade às relações entre particulares.

Quanto à metodologia empregada, a presente pesquisa possui caráter bibliográfico, explorando material já publicado formado por textos doutrinários e decisões judiciais. A doutrina foi selecionada a partir da relevância para compreensão dos julgados (principal objeto de análise). Os casos, por sua vez, foram selecionados na jurisprudência do Supremo Tribunal Federal posterior à promulgação da Constituição de 1988, tendo em vista que é o órgão jurisdicional que tem como função precípua a análise das normas constitucionais e, por consequência, dos direitos fundamentais. A seleção temporal se deu considerando a necessidade de um ambiente democrático para adequada compreensão da liberdade de expressão, como será desenvolvido melhor no decorrer do trabalho. Por fim, aplica um método dialético, uma vez que será necessário um confronto entre as decisões e entre as decisões e a doutrina para, a partir dessa contradição, desenvolver possíveis conclusões.

Para isso, foram selecionados cinco casos que marcaram a posição da Corte e que podem ser destacados como a base para a construção do conceito de liberdade de pensamento, com a definição de limites. São eles: (i) caso Ellwanger, julgamento do HC 82.424-2, considerado o mais antigo, desde a vigência da atual Constituição, sendo finalizado em outubro de 2003²; (ii) caso da restrição de manifestação na Praça dos Três Poderes, proposto na ADI 1.969-4, julgada

\footnotetext{
2 BRASIL. Supremo Tribunal Federal. Tribunal Pleno. Acórdão da decisão do caso Ellwanger. HC 82424-2. Relator para Acórdão: Ministro Maurício Corrêa. Julgado em: 17/09/2003. Publicado em: DJ 19/03/2004. Disponível em: http://redir.stf.jus.br/paginadorpub/paginador.jsp?docTP=AC\&doclD=79052. Acesso em: 25 mar. 2019.
} 
ISSN 1981-3694

(DOI): $10.5902 / 1981369437843$

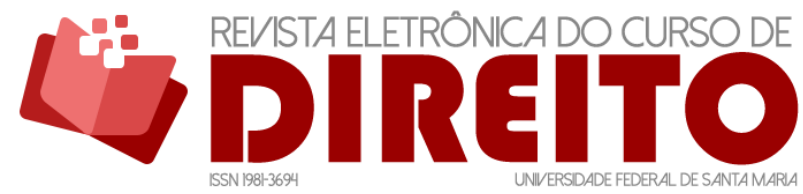

PROTEÇÃO DOS PARTICULARES E CENSURA PRIVADA: A JURISPRUDÊNCIA CONSTITUCIONAL SOBRE OS LIMITES À LIBERDADE DE EXPRESSÃO

ELDEN BORGES SOUZA VICTOR SALES PINHEIRO

em 200733 (iii) caso da recepção da Lei de Imprensa (lei n. 5.250/67), discutido na ADPF 1304; (iv) caso da "Marcha da Maconha", proposto na ADPF 1875; e, por fim, o (v) caso da publicação de biografias não autorizadas, objeto da ADI $4.815^{6}$.

Primeiramente será apresentada a relação entre a democracia e a liberdade de expressão para que, então, se torne possível compreender o contexto no qual o Supremo Tribunal Federal (STF) estava inserido e a influência desta relação como ponto referencial para o desfecho de seus julgados. Em seguida, será demonstrado um breve resumo dos fatos e dos principais argumentos usados na decisão dos casos citados. Por fim, após demonstrar os principais conceitos relacionados à liberdade de pensamento já consolidados no STF, analisar-seá a aplicação e os limites à liberdade de expressão em relações entre particulares.

\section{DEMOCRACIA, LIBERDADE DE EXPRESSÃO, SEUS LIMITES E MÉTODOS DE RESTRIÇÃO}

A liberdade de expressão foi uma reivindicação das revoluções burguesas. Esse período revolucionário é considerado por Dimoulis e Martins como o real nascimento dos direitos fundamentais ${ }^{7}$. Apesar de autores como Comparato ${ }^{8}$ e Villey ${ }^{9}$ encontrarem vestígios de direitos humanos (lato sensu) desde a Idade Antiga, como em Aristóteles, somente com a organização de um Estado, com a noção de indivíduo e com a edição de um instrumento que proteja esses

\footnotetext{
3 BRASIL. Supremo Tribunal Federal. Tribunal Pleno. Acórdão da decisão do caso da manifestação na Praça dos Três Poderes. ADI 1969. Relator: Min. Ricardo Lewandowski. Julgado em: 28/06/2007. Publicado em: DJ 31/08/2007. Disponível em: http: //redir.stf.jus.br/paginadorpub/paginador.jsp?docTP=AC\&doclD=484308. Acesso em: 25 mar. 2019.

${ }^{4}$ BRASIL. Supremo Tribunal Federal. Tribunal Pleno. Acórdão da decisão do caso da Lei de Imprensa. ADPF 130. Relator: Ministro Carlos Britto. Julgado em: 30/04/2009. Publicado em: DJe-208 06/11/2009. Disponível em: http://redir.stf.jus.br/paginadorpub/paginador.jsp?docTP=AC\&docID=605411. Acesso em: 25 mar. 2019.

${ }^{5}$ BRASIL. Supremo Tribunal Federal. Tribunal Pleno. Acórdão da decisão do caso da marcha da maconha. ADPF 187. Relator: Min. Celso de Mello Julgado em 15/06/2011, Publicado em: 29/05/2014. Disponível em: http://redir.stf.jus.br/paginadorpub/paginador.jsp?docTP=TP\&doclD=5956195. Acesso em: $25 \mathrm{mar}$. 2019.

${ }^{6}$ BRASIL. Supremo Tribunal Federal. Tribunal Pleno. Acórdão da decisão do caso das biografias não autorizadas. ADI 4815. Relatora para Acórdão: Ministra Cármen Lúcia. Julgado em: 10/06/2015. Publicado em: DJ 01/02/2016. Disponível em: http://redir.stf.jus.br/paginadorpub/paginador.jsp?docTP=TP\&docID=10162709. Acesso em: 25 mar. 2019. 7 DIMOULIS, Dimitri; MARTINS, Leonardo. Teoria Geral dos Direitos Fundamentais. 2. ed. São Paulo: Editora Revista dos Tribunais, 2009.

8 COMPARATO, Fábio Konder. A Afirmação Histórica dos Direitos Humanos. 5. ed. São Paulo: Saraiva, 2007.

${ }^{9}$ VILLEY, Michel. O Direito e os Direitos Humanos. São Paulo: WMF Martins Fontes, 2007.
} 
ISSN 1981-3694

(DOI): $10.5902 / 1981369437843$

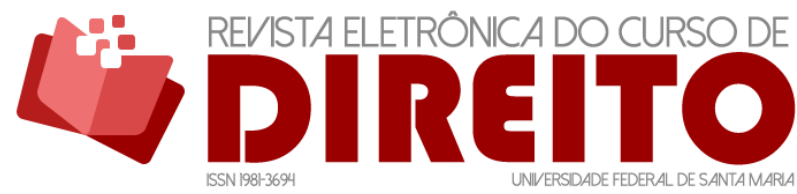

PROTEÇÃO DOS PARTICULARES E CENSURA PRIVADA: A JURISPRUDÊNCIA CONSTITUCIONAL SOBRE OS LIMITES À LIBERDADE DE EXPRESSÃO

ELDEN BORGES SOUZA VICTOR SALES PINHEIRO

indivíduos em face do Estado, a Constituição, é que podem ser afirmados reais, e não ideais, direitos fundamentais.

O fato de tal liberdade ser um direito fundamental é de suma importância para constatar a sua posição no ordenamento jurídico. Os direitos fundamentais apresentam determinadas características que os diferenciam das demais normas jurídicas, dando-lhes uma posição especial e de destaque. Efetivamente, o Estado Democrático de Direito é caracterizado, em essência, por ter no ápice de seu sistema jurídico os direitos fundamentais. São uma conditio sine qua non do Estado Constitucional ${ }^{10}$.

Tais direitos possuem diversas funções em um Estado e dentro do sistema jurídico. Duas merecem destaque para explicar a liberdade de expressão: os direitos fundamentais como parâmetro de atuação do Governo e os direitos fundamentais como condicionantes exegéticos do ordenamento. Essa segunda função é essencial para compreender a incidência da liberdade de expressão sobre relações privadas.

No primeiro sentido, percebe-se que os direitos fundamentais possuem uma íntima relação com a democracia, em virtude, entre outros aspectos, de sua proteção à liberdade em geral, à autonomia individual, como afirma Sarlet:

[...] os direitos fundamentais podem ser considerados simultaneamente pressuposto, garantia e instrumento do princípio democrático da autodeterminação do povo por intermédio de cada indivíduo, mediante o reconhecimento do direito à igualdade (perante a lei e de oportunidades), de um espaço de liberdade real, bem como por meio da outorga do direito à participação (com liberdade e igualdade), na conformação da comunidade e do processo político $[\ldots]^{11}$.

Em que pese o caráter eminentemente individual da liberdade de expressão, deve ser observado que existem outros interesses sobre o pensamento veiculado. Na realidade, podem ser identificados três interesses sobre a mensagem: o emissor, sendo sempre o núcleo central na análise deste direito; a audiência, aqueles a quem se destina o discurso; e os terceiros, que são atingidos de forma reflexa.

A análise da liberdade de expressão em relação à democracia é a avaliação de seu impacto na audiência. Ou seja, quando se busca fazer tal análise, o interessado em destaque será o público, aqueles que podem formar ou mudar sua posição. Nesse sentido, direciona-se às pessoas, tendo um reflexo sobre o Estado.

10 SARLET, Ingo Wolfgang. A Eficácia dos Direitos Fundamentais. 10. ed. Porto Alegre: Livraria do Advogado Editora, 2010, p. 59.

11 Ibidem, p. 61. 
ISSN 1981-3694

(DOI): $10.5902 / 1981369437843$

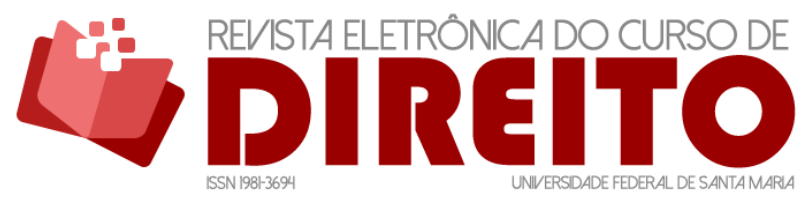

PROTEÇ̃̃O DOS PARTICULARES E CENSURA PRIVADA: A JURISPRUDÊNCIA CONSTITUCIONAL SOBRE OS LIMITES À LIBERDADE DE EXPRESSÃO

ELDEN BORGES SOUZA VICTOR SALES PINHEIRO

No entanto, como qualquer valor constitucional, esta liberdade não é absoluta nem superior a qualquer outro princípio inscrito em nosso Estatuto Jurídico, conforme o postulado hermenêutico da unidade da Constituição ${ }^{12}$. Mesmo assim, enquanto direito fundamental, sua interpretação deve buscar sempre a maior eficácia, o que implica limites mínimos e estritamente necessários.

De início, devemos compreender que a liberdade de expressão possui um amplo âmbito de abrangência. Vale ressaltar que, conforme a teoria do suporte fático amplo, o âmbito de proteção dos direitos fundamentais deve ser interpretado de forma ampla - abrangendo, prima facie, qualquer conduta em abstrato por ele tutelada ${ }^{13}$. Por isso, as mais diversas e controversas manifestações são, em regra, tuteladas pela liberdade de expressão, mas, conforme ponderação posterior, podem vir a ser limitadas. No entanto, essa proteção é prima facie, não significando que, ao final da avaliação, toda e qualquer manifestação será aceita.

A doutrina já trabalhou algumas situações que configuram limites, sistematizando alguns, entre eles: o Princípio do Dano, o Perigo Real e Iminente (Clear and Present Danger), as Palavras Agressivas (Fighting Words), o Discurso do Ódio, os direitos de terceiros, o dever de verdade e o direito ao esquecimento ${ }^{14}$. Enquanto alguns desses limites são relativamente pacíficos, outros são extremamente controvertidos, variando conforme a concepção política e jurídica do intérprete.

Em todo caso, o ponto de partida para análise dos limites e das formas de restrição à liberdade de expressão é o denominado Princípio do Dano, defendido classicamente por Stuart Mill ${ }^{15}$. Tal princípio não é comumente abordado nomeadamente, no entanto seu conteúdo é reiteradamente utilizado para justificar restrições a essas liberdades. Alfredo Varela, propositalmente ou não, define-o ao afirmar:

\footnotetext{
12 BASTOS, Celso Ribeiro. Hermenêutica e Interpretação Constitucional. 2. ed. São Paulo: IBDC, 1999, p. 103.

${ }^{13}$ Sobre a teoria do suporte fático amplo e porque é a mais adequada a um regime democrático de direitos fundamentais como o da Constituição Brasileira de 1988, ver: SILVA, Virgílio Afonso da. O conteúdo essencial dos direitos fundamentais e a eficácia das normas constitucionais. Revista de Direito do Estado, v. 4, pp. 23-51, 2006.

${ }^{14}$ MEYER-PFLUG, Samantha Ribeiro. Liberdade de expressão e discurso do ódio. São Paulo: Revista dos Tribunais, 2009. Sendo que, com o avanço das redes sociais, tem havido um crescente debate sobre a difusão de discursos de ódio na internet. Sobre esse tema, cf.: STROPPA, Tatiana; ROTHENBURG, Walter Claudius. Liberdade de expressão e discurso do ódio: o conflito discursivo nas redes sociais. Revista Eletrônica do Curso de Direito da UFSM, Santa Maria, RS, v. 10, n. 2, p. 450-468, dez. 2015. ISSN 19813694. Disponível em: https://periodicos.ufsm.br/revistadireito/article/view/19463. Acesso em: $25 \mathrm{abr}$. 2019. doi: http://dx.doi.org/10.5902/1981369419463.

${ }^{15}$ MILL, John Stuart. Sobre a liberdade. São Paulo: Saraiva, 2011.
} 
ISSN 1981-3694

(DOI): $10.5902 / 1981369437843$

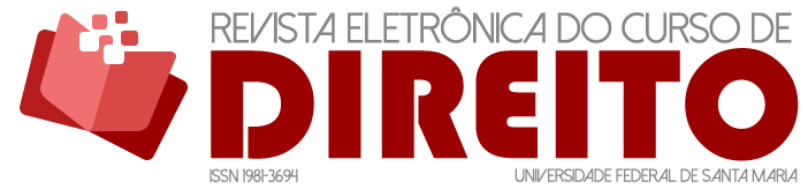

PROTEÇÃO DOS PARTICULARES E CENSURA PRIVADA: A JURISPRUDÊNCIA CONSTITUCIONAL SOBRE OS LIMITES À LIBERDADE DE EXPRESSÃO

ELDEN BORGES SOUZA VICTOR SALES PINHEIRO

Em meio da diversidade imensa de opiniões, o governo, para não ser desacatado e favorecer a formação de uma legítima opinião pública, há de ser neutro, absolutamente neutro, restringindo-se seu papel a prevenir os conflitos possíveis e castigar os autores dos que não possam ser evitados, e a alguns poucos atos mais, alheios à atividade particular ${ }^{16}$.

Assim, para que haja limitação à liberdade de expressão, é necessário encontrar um dano concreto em outro valor constitucional, ou seja, de mesma hierarquia. Assim, quando ocorrem esses limites, quase sempre é caso de colisão de direitos fundamentais. Sobre a limitação afirma Gilberto Jabur:

Se, por um lado, não se pode limitar a atividade intelectual do homem, pode-se e deve-se, por outro lado, restringir a exteriorização de seu pensamento, impondo-lhe - a fim de evitar a supremacia dessa primeira atividade humana em detrimento de outras não menos fundamentais - limites racionalizados, conformadores do Estado de Direito, indispensáveis a um saudável pluralismo político e ideológico, sustentáculo do regime democrático que facilita e amplia o exercício dos demais direitos da pessoa ${ }^{17}$.

Trata-se da tentativa de promover a harmonia constitucional. Ou seja, existem diversos interesses constitucionais em jogo, todos dignos de tutela e de efetivação, que concorrem uns com os outros. Nesse caso, deve-se tentar efetivar ao máximo todos, restringindo-se conforme a máxima proporcionalidade ${ }^{18}$.

No entanto, o princípio do dano não significa que o Judiciário apenas pode intervir quando a violação já se concretizou. Ou seja, a noção de dano concreto trata de uma situação de colisão concreta e real, e não meramente abstrata ou potencial, que pode com grande e razoável probabilidade, causar lesão a outro valor constitucional. Dessa forma, é possível uma ponderação que culmine com uma restrição prévia, quando o risco da produção de um dano justifique a vedação antecipada da expressão ${ }^{19}$.

Vê-se, assim, que o principal fundamento para limitação da liberdade de expressão é a relação entre particulares que, por sua vez, é necessariamente mediada por direitos fundamentais. Ou seja, o potencial dano que pode ser causado pela expressão de alguém sobre direitos fundamentais de outra pessoa. Aparentemente, é difícil identificar restrições legítimas a

\footnotetext{
${ }^{16}$ VARELA, Alfredo. Direito Constitucional Brasileiro. Brasília: Senado Federal, 2002, p. 263.

17 JABUR, Gilberto Haddad. Liberdade de Pensamento e Direito à Vida Privada. São Paulo: Revista dos Tribunais, 2000, p. 159.

18 FARIAS, Edilsom Pereira de. Colisão de direitos: a honra, a intimidade, a vida privada e a imagem versus a liberdade de expressão e informação. 2. ed. Porto Alegre: Sergio Antonio Fabris Editor, 2000, p. 175.

19 TOLLER, Fernando M. O Formalismo na Liberdade de Expressão. São Paulo: Saraiva, 2010.
} 
ISSN 1981-3694

(DOI): $10.5902 / 1981369437843$

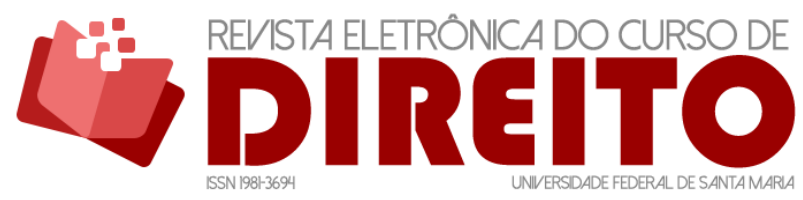

PROTEÇ̃̃O DOS PARTICULARES E CENSURA PRIVADA: A JURISPRUDÊNCIA CONSTITUCIONAL SOBRE OS LIMITES À LIBERDADE DE EXPRESSÃO

ELDEN BORGES SOUZA VICTOR SALES PINHEIRO

essa liberdade com base em interesses puramente estatais, embora possam existir. Em todo caso, essas limitações fogem ao objeto do presente trabalho.

Tendo em mente essas considerações iniciais, para compreender-se seu real significado é imprescindível a análise jurisprudencial. Nesse sentido, a jurisprudência do Supremo Tribunal Federal é a base.

\section{O CASO ELLWANGER E A ABRANGÊNCIA DA LIBERDADE}

Considerando a vigência da atual Constituição, o caso mais antigo foi o julgamento do HC 82.424-2, finalizado em outubro de $2003^{20}$. Esse caso discutiu a possibilidade de Ellwanger escrever um livro negando o Holocausto e atribuindo a "responsabilidade" pela $2^{\text {a }}$ Guerra Mundial aos judeus. A maioria entendeu que tal conduta caracterizava racismo. No entanto, os ministros Marco Aurélio e Ayres Britto defenderam que a liberdade de expressão admitia esses pensamentos minoritários e "desagradáveis".

De início, a discussão centrou-se no conceito de raça e de racismo ${ }^{21}$. Trata-se de discussão de ocupa relevante parte do acórdão, porém sem grande relação com o objeto do presente trabalho. Os ministros Moreira Alves e Marco Aurélio apreenderam esses conceitos a partir de uma análise histórica e semântica. Sendo assim, o conceito raça seria utilizado para distinguir os diferentes grupos do gênero humano, brancos, amarelos e negros, e não outros grupos, como os judeus.

Capitaneados pelo ministro Maurício Corrêa, os demais fizeram uma interpretação teleológica da norma, dando aos termos um conceito histórico, sociológico e cultural. Esta corrente entendeu o racismo como fenômeno social pelo qual um grupo é considerado raça “racialização", como ocorre com os judeus. Assim, o antissemitismo é racismo.

Nesse sentido, a maioria dos ministros entendeu que o ato em si de publicar e editar livros pode ser considerado meio idôneo para a prática da discriminação, vencido o ministro Ayres Britto. Sepúlveda Pertence deixou claro que, como regra, os livros não têm essa capacidade, todavia, em casos excepcionais, esta conduta pode ser considerada meio executivo para tal crime. Se o livro tivesse ficado apenas no plano das ideias, não poderia ser interpretado

\footnotetext{
${ }^{20}$ BRASIL. Supremo Tribunal Federal. Tribunal Pleno. Acórdão da decisão do caso Ellwanger. HC 82424-2. Relator para Acórdão: Ministro Maurício Corrêa. Julgado em: 17/09/2003. Publicado em: DJ 19/03/2004. Disponível em: http://redir.stf.jus.br/paginadorpub/paginador.jsp?docTP=AC\&doclD=79052. Acesso em: 25 mar. 2019.

21 Ibidem, pp. 35 e ss.
} 
ISSN 1981-3694

(DOI): $10.5902 / 1981369437843$

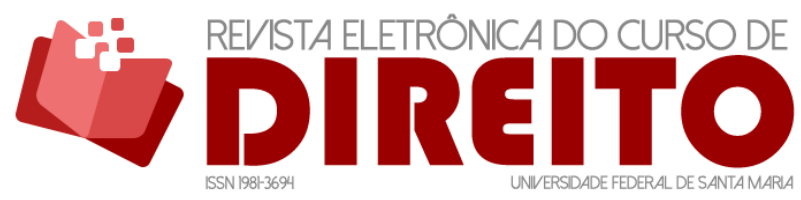

PROTEÇ̃̃O DOS PARTICULARES E CENSURA PRIVADA: A JURISPRUDÊNCIA CONSTITUCIONAL SOBRE OS LIMITES À LIBERDADE DE EXPRESSÃO

ELDEN BORGES SOUZA VICTOR SALES PINHEIRO

como prática. Contudo, a sua publicação tem o potencial de transbordar o campo da liberdade de expressão e induzir ou instigar o racismo ${ }^{22}$. Concordante, Nelson Jobim afirmou que a edição do livro não constitui prática de racismo, mas a forma como ela foi utilizada, sim. A finalidade panfletária pretendida foi que constituiu o crime.

Demais disso, os ministros debateram sobre estarem ou não protegidas pela liberdade de expressão as condutas de editar e publicar aqueles livros.

Maurício Corrêa entendeu que não houve violação ao princípio da liberdade de expressão, pois, além de não ser incondicional, ele tem uma restrição imediata uma vez que a Constituição não autoriza o direito à incitação ao racismo. Assim sendo, neste caso sequer haveria colisão de direitos fundamentais, tendo em vista que um direito individual não pode servir de salvaguarda a práticas ilícitas. A ponderação, então, teria sido feita pelo próprio Texto Constitucional.

Celso de Mello seguiu a mesma linha, entendendo que a liberdade de expressão é essencial a uma sociedade democrática, porém não de forma absoluta e nem comportando uma incitação ao ódio público contra o povo judeu. Para ele, a manifestação racista e o "discurso do ódio" estão fora do âmbito de abrangência dessa liberdade, que é limitado pela dignidade humana e igualdade. Tais publicações "extravasam os limites da indagação científica e da pesquisa histórica, degradando-se ao nível primário do insulto, da ofensa $e$, sobretudo, do estímulo à intolerância e ao ódio público pelos judeus" ${ }^{23}$. Assim, a liberdade de expressão, por mais ampla que seja, não protegeria a violação de outros valores igualmente constitucionais.

No mesmo sentido, Carlos Velloso ressaltou o caráter panfletário da publicação. Ao encontrar uma incitação ao ódio público contra os judeus, afastou a proteção da liberdade de expressão. Destacou a inexistência de direitos absolutos, enfatizando a garantia do sistema de proteção dos direitos e garantias fundamentais.

Para Cezar Peluso, enquanto editor e autor, houve o exercício da liberdade de expressão, porém de forma abusiva e desvirtuada. O comportamento sistemático foi reprovável, transpondo os limites da liberdade de expressão. Deveria prevalecer a igualdade pretendida pelos judeus.

Ayres Britto identificou claramente uma oposição de princípios - inclusive foi quem mais discorreu sobre a liberdade de opinião e expressão. Para ele, tal liberdade garante o direito de

${ }^{22}$ BRASIL. Supremo Tribunal Federal. Tribunal Pleno. Acórdão da decisão do caso Ellwanger. HC 82424-2. Relator para Acórdão: Ministro Maurício Corrêa. Julgado em: 17/09/2003, pp. 480 e ss. Publicado em: DJ 19/03/2004. Disponível em: http://redir.stf.jus.br/paginadorpub/paginador.jsp?docTP=AC\&doclD=79052. Acesso em: 25 mar. 2019.

${ }^{23}$ Ibidem, p. 105, grifos no original. 
ISSN 1981-3694

(DOI): $10.5902 / 1981369437843$

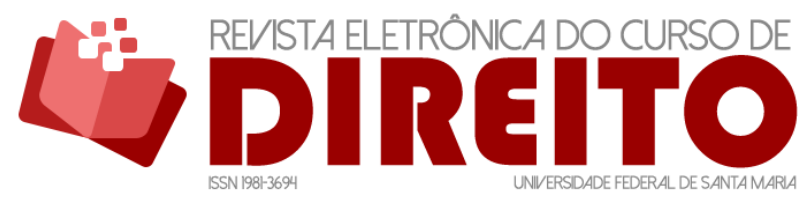

PROTEÇ̃̃O DOS PARTICULARES E CENSURA PRIVADA: A JURISPRUDÊNCIA CONSTITUCIONAL SOBRE OS LIMITES À LIBERDADE DE EXPRESSÃO

ELDEN BORGES SOUZA VICTOR SALES PINHEIRO

manifestação, mas nisto há o exaurimento do direito subjetivo. Ela não garante imunidade posteriormente, vez que terceiros podem exigir a reparação pelo conteúdo abusivo que foi expresso. Ou seja, na exposição da opinião exaure-se o direito subjetivo - que impede a censura prévia. Por fim, considerou que a liberdade de expressão foi utilizada para manifestar uma posição política - o que não é errado.

Por outro lado, Gilmar Mendes ressaltou a importância da liberdade de expressão e da igualdade para a democracia. Também identificou uma colisão de direitos fundamentais: entre a liberdade de expressão e o direito à não discriminação, caracterizado como discurso do ódio ${ }^{24}$. Após realizar uma análise da postura do agente em relação à norma penal, raciocínio subsunsivo, aplicou o método da proporcionalidade para confirmar ou rechaçar a tipificação, uma vez que o tipo é aberto. Dessa forma, chegou à conclusão de que a liberdade de expressão não afastava a tipicidade da conduta.

Segundo Marco Aurélio, as condutas elencadas no processo seriam autorizadas a todos, devido à ampla abrangência do princípio da liberdade de expressão, basilar nas sociedades democráticas e esteio do princípio da dignidade da pessoa humana. Também realizou uma ponderação de interesses, afastando com isso a tipicidade da conduta. Para o ministro, a abrangência da liberdade de expressão e seu consequente caráter fundamental para sociedade democrática tem o condão de afastar a tipicidade da conduta do agente quanto ao crime de racismo, mas não em relação à discriminação lato sensu.

Também observou que a determinação da pena não é adequada para eliminar discussão pública sobre o assunto, nem é necessária, porque ela não consegue preservar a dignidade do povo judeu. Segundo Marco Aurélio, livros não seriam capazes de ferir a dignidade humana, vez que o simples ato de publicação não tem consequência obrigatória de influenciar na decisão das pessoas. Destarte, a conduta de Ellwanger também não seria razoável, já que não alcança o objetivo pretendido com a limitação da liberdade de expressão.

Sendo assim, por maioria de votos não foi declarada a extinção da punibilidade, sendo mantida a condenação de Ellwanger pelo antissemitismo de sua obra.

Nessa primeira decisão ficou claro, embora sem uma expressão da maior parte dos ministros, que a liberdade de expressão tem aplicação sobre as relações particulares. Como no

\footnotetext{
${ }^{24}$ BRASIL. Supremo Tribunal Federal. Tribunal Pleno. Acórdão da decisão do caso Ellwanger. HC 82424-2. Relator para Acórdão: Ministro Maurício Corrêa. Julgado em: 17/09/2003, pp. 126 e ss. Publicado em: DJ 19/03/2004. Disponível em: http://redir.stf.jus.br/paginadorpub/paginador.jsp?docTP=AC\&docID=79052. Acesso em: 25 mar. 2019.
} 
ISSN 1981-3694

(DOI): $10.5902 / 1981369437843$

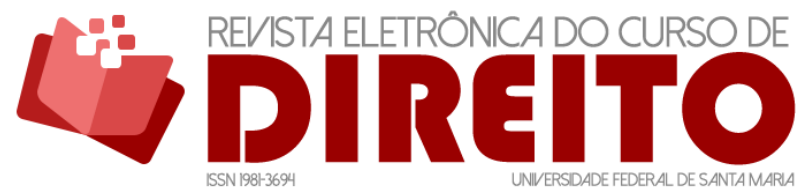

PROTEÇ̃̃O DOS PARTICULARES E CENSURA PRIVADA: A JURISPRUDÊNCIA CONSTITUCIONAL SOBRE OS LIMITES À LIBERDADE DE EXPRESSÃO

ELDEN BORGES SOUZA VICTOR SALES PINHEIRO

conhecido Caso Lüth ${ }^{25}$, o Supremo Tribunal Federal admitiu que tal liberdade pode culminar na proteção de uma determinada conduta em face de interesses de outros particulares. No entanto, o Tribunal também reconheceu que esse direito não ampara qualquer conduta, como a difusão do ódio e a ofensa a grupos minoritários.

\section{CASO DA MANIFESTAÇÃO NA PRAÇA DOS TRÊS PODERES E A PROTEÇÃO DA EFETIVIDADE DA LIBERDADE}

Em 28 de junho de 2007, o Supremo julgou a ADI 1.969-4 ${ }^{26}$. Nesse caso o STF foi chamado para decidir se um decreto do Executivo do Distrito Federal que restringia a manifestação na Praça dos Três Poderes era constitucional. Inicialmente, o decreto proibia manifestações na Esplanada dos Ministérios e na Praça dos Três Poderes. Após algumas alterações, passou a permitir manifestações, desde que silenciosas. Por unanimidade considerouse que havia violação da liberdade de manifestação pública. 0 acórdão foi no sentido de que as limitações à liberdade de manifestação, para serem admissíveis, devem ser proporcionais.

O ministro Marco Aurélio, relator da cautelar, votou no sentido de que a liberdade de reunião possui uma condição diferenciada, devendo ser restringida apenas quando extrapolar os limites da razoabilidade. Sendo que a lei do silêncio, por tornar inócua a liberdade de expressão, viola a Constituição. Por outro lado, Nelson Jobim ressaltou que este direito não é absoluto e, portanto, não pode impedir o gozo de outras faculdades constitucionais. Assim, uma restrição sonora seria admissível próximo a um hospital, por exemplo.

Octavio Gallotti, Sydney Sanches e Néri da Silveira acompanharam tal noção de relatividade de todos os direitos fundamentais, inclusive da liberdade de pensamento. Moreira Alves deixou consignado que a democracia exige ordem e, portanto, permite a utilização do poder de polícia. Dessa forma, podem ser proibidas manifestações em locais específicos, desde que conforme um critério de razoabilidade - o que não estaria presente no caso específico.

No julgamento de mérito, já com uma composição bastante diferenciada, o Tribunal destacou diversos pontos relevantes quanto à liberdade de reunião e quanto à liberdade de

\footnotetext{
${ }^{25}$ SCHWAB, Jürgen. Cinquenta anos de Jurisprudência do Tribunal Constitucional Alemão. Montevidéu: Fundação Konrad Adenauer Stiftung, 2006, pp. 381 e ss.

${ }^{26}$ BRASIL. Supremo Tribunal Federal. Tribunal Pleno. Acórdão da decisão do caso da manifestação na Praça dos Três Poderes. ADI 1969. Relator: Min. Ricardo Lewandowski. Julgado em: 28/06/2007. Publicado em: DJ 31/08/2007. Disponível em: http://redir.stf.jus.br/paginadorpub/paginador.jsp?docTP=AC\&docID=484308. Acesso em: 25 mar. 2019.
} 
ISSN 1981-3694

(DOI): $10.5902 / 1981369437843$

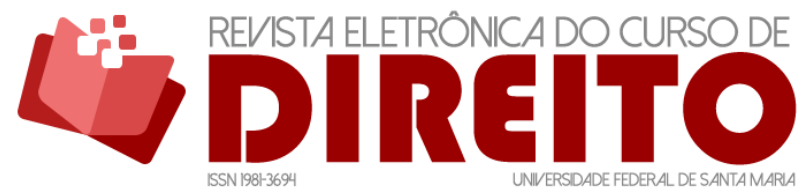

PROTEÇ̃̃O DOS PARTICULARES E CENSURA PRIVADA: A JURISPRUDÊNCIA CONSTITUCIONAL SOBRE OS LIMITES À LIBERDADE DE EXPRESSÃO

ELDEN BORGES SOUZA VICTOR SALES PINHEIRO

pensamento. No mérito, o ministro Ricardo Lewandowski destacou a liberdade de reunião como uma das mais importantes conquistas e fundamento das democracias modernas ${ }^{27}$. Citando diversos autores, o relator apontou a liberdade de reunião como um direito de caráter individual e coletivo neste aspecto, enquanto atuação de grupos sociais. Consignou também que o direito de reunião é uma face da liberdade de expressão, sendo meio de formação da vontade política.

Após reconhecer que este direito não é absoluto, o relator apontou que as restrições não presentes na Constituição decorrem de lei autorizada constitucionalmente ou por colisão de direitos. No caso, por um lado o decreto não afere concretamente a colisão e, por outro lado, retira completamente a eficácia do direito de reunião e da liberdade de expressão ao proibir o protesto no principal espaço político de Brasília, quiçá do Brasil, ou torná-lo inócuo ao exigir um protesto silencioso. Portanto, uma restrição desproporcional ${ }^{28}$. Nesse sentido, votou pela declaração de inconstitucionalidade do decreto distrital.

Eros Grau acompanhou o relator, porém com fundamento em uma inconstitucionalidade formal. Segundo o ministro, a liberdade de reunião até poderia ser regulamentada no plano infraconstitucional, mas não por decreto e sim por $l \mathrm{ei}^{29}$.

Seguindo o relator, porém em sentido oposto ao de Eros Grau, Sepúlveda Pertence ressaltou que a CRFB/88 ficou silente quanto à possibilidade de edição de ato infraconstitucional na matéria. Dessa forma, defendeu o ministro, o silêncio da Constituição deve ser interpretado como uma vedação a qualquer regulação legal ${ }^{30}$.

Os ministros Celso de Mello, Ayres Britto, Cármen Lúcia e Cezar Peluso seguiram o posicionamento e os fundamentos apresentados pelo relator, ressaltando a importância do direito de reunião e de protesto às democracias e a ampla proteção e regulamentação conferida pela Constituição da República de 1988. No entanto, não se posicionaram sobre a possibilidade ou não de edição de lei na matéria.

Sendo assim, à unanimidade o Tribunal declarou a inconstitucionalidade do decreto distrital, estabelecendo um marco quanto à liberdade de reunião.

\footnotetext{
27 BRASIL. Supremo Tribunal Federal. Tribunal Pleno. Acórdão da decisão do caso da manifestação na Praça dos Três Poderes. ADI 1969. Relator: Min. Ricardo Lewandowski. Julgado em: 28/06/2007, p. 11. Publicado em: DJ 31/08/2007. Disponível em: http: / /redir.stf.jus.br/paginadorpub/paginador.jsp?docTP=AC\&doclD=484308. Acesso em: 25 mar. 2019.

28 Ibidem, p. 18.

${ }^{29}$ BRASIL. Supremo Tribunal Federal. Tribunal Pleno. Acórdão da decisão do caso da manifestação na Praça dos Três Poderes. ADI 1969. Relator: Min. Ricardo Lewandowski. Julgado em: 28/06/2007, p. 22. Publicado em: DJ 31/08/2007. Disponível em: http: / /redir.stf.jus.br/paginadorpub/paginador.jsp?docTP=AC\&doclD=484308. Acesso em: 25 mar. 2019.

${ }_{30}$ Ibidem, p. 40.
} 
ISSN 1981-3694

(DOI): $10.5902 / 1981369437843$

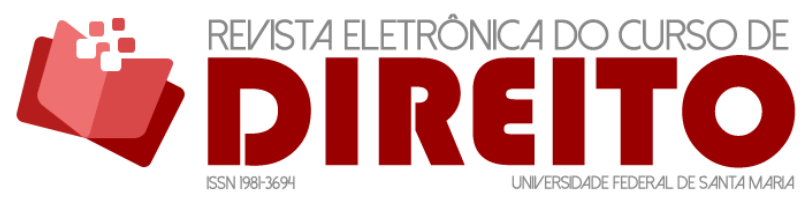

PROTEÇ̃̃ DOS PARTICULARES E CENSURA PRIVADA: A JURISPRUDÊNCIA CONSTITUCIONAL SOBRE OS LIMITES À LIBERDADE DE EXPRESSÃO

ELDEN BORGES SOUZA VICTOR SALES PINHEIRO

Embora este seja um caso voltado contra o Poder Público, não estando relacionado às relações privadas, em verdade ele tem um papel importante na jurisprudência constitucional. Neste precedente o Tribunal definiu um conceito amplo de liberdade de expressão, estabelecendo que uma limitação à forma ou ao alcance da expressão do pensamento, por meio da inclusão de restrições que dificultam o alcance da audiência, tornando inócuo o discurso, são uma violação à Constituição.

\section{O CASO DA LEI DE IMPRENSA E O STATUS JURÍDICO DA LIBERDADE}

$\mathrm{Na}$ ADPF 130 a discussão posta era sobre a recepção da Lei de Imprensa Lei n. $5.250 / 67^{31}$. Destaca-se nesse julgamento a posição do relator, ministro Ayres Britto, de que a liberdade de imprensa, consectário da liberdade de expressão, é digna de uma sobretutela. Assim, a maioria declarou a não recepção portanto, a contrariedade à atual Constituição, da citada lei. Os ministros vencidos divergiam apenas para limitar o alcance da decisão, afirmando que alguns dispositivos foram recepcionados.

O relator fez um longo voto destacando diversos pontos sobre a liberdade de pensamento e de imprensa. Inicialmente, destacou os dois conceitos de imprensa: enquanto atividade - agir comunicativo humano - e enquanto instituição - conjunto de órgãos e instituições que propiciam tal comunicação ${ }^{32}$.

Outro argumento relevante do voto do relator foi a identificação da imprensa como uma segunda opinião ou segundo meio de conhecimento dos fatos e opiniões existentes. Assim, a imprensa possibilita o conhecimento das diversas faces e posições sobre um tema - propiciando o pluralismo, e, então, permite a formação da opinião pública. E mais, de forma livre, a imprensa cria um canal de controle do Poder pela sociedade ${ }^{33}$.

Prosseguindo, o ministro ressaltou como, igualmente, a imprensa possui o dever de informar com o máximo de fidedignidade, ou seja, o objetivo da imprensa é informar a verdade, Ou, partindo da ideia de que esta não é um dado objetivamente alcançável, permitir que a audiência possa formar sua verdade.

31 BRASIL. Supremo Tribunal Federal. Tribunal Pleno. Acórdão da decisão do caso da Lei de Imprensa. ADPF 130. Relator: Ministro Carlos Britto. Julgado em: 30/04/2009. Publicado em: DJe-208 06/11/2009. Disponível em: http://redir.stf.jus.br/paginadorpub/paginador.jsp?docTP=AC\&doclD=605411. Acesso em: 25 mar. 2019.

32 Ibidem, pp. 22 e ss.

33 Ibidem, pp. 28 e ss. 
ISSN 1981-3694

(DOI): $10.5902 / 1981369437843$

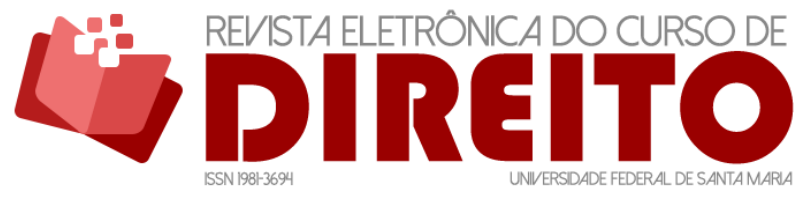

PROTEÇ̃̃O DOS PARTICULARES E CENSURA PRIVADA: A JURISPRUDÊNCIA CONSTITUCIONAL SOBRE OS LIMITES À LIBERDADE DE EXPRESSÃO

ELDEN BORGES SOUZA VICTOR SALES PINHEIRO

A imprensa também é indissociável do conceito de cidadania. Efetivamente, a liberdade de imprensa assegura ao cidadão o direito de conhecer e acompanhar o que acontece com o Poder. Sendo que a liberdade de manifestação do pensamento é ampliada quando veiculada pela imprensa, recebe uma sobretutela, diz o relator. Dessa forma, nega à lei a possibilidade de tratar da matéria inteiramente constitucional, na sua posição.

Um ponto relevante no voto do ministro é a posição de que a ponderação sobre a liberdade de expressão já foi feita pela Constituição, e foi resolvida em favor desta. Dessa forma, os direitos de personalidade somente expressar-se-iam posteriormente à manifestação do pensamento, por meio da responsabilidade civil, penal ou direito de resposta. Para concluir, em que pese seu voto pelo afastamento total da lei de imprensa, o relator destacou sua preocupação com a ausência de regulação sobre o direito de resposta, que a lei de imprensa instrumentalizava de forma detalhada, e a eliminação da prisão especial para jornalistas.

Por sua vez, Eros Grau ratificou seu voto proferido no julgamento da medida liminar, declarando como não recepcionada a integralidade da lei de imprensa. No voto da cautelar o ministro destacou que a lei de imprensa faz parte dos restos autoritários do Regime Militar, portanto totalmente incompatível com a Carta de 1988.

Menezes Direito acompanhou o relator na importância da imprensa para a democracia e para o controle do Estado. Enfatiza que a democracia é marcada pela liberdade de expressão e não pelo voto, pois os regimes totalitários convivem com este, mas não com aquela ${ }^{34}$. Porém, a democracia depende também do respeito à dignidade da pessoa humana.

Nesse sentido, o ministro destaca que a CRFB/88 também deu ênfase aos direitos da personalidade. Assim, o confronto destes com a liberdade de expressão deve ser solucionado pela ponderação, que não admite nenhum direito como absoluto. Os limites são necessários à harmonia dos direitos e à convivência humana. No entanto, tais restrições devem ser compatíveis com a Constituição; como isto não ocorreu com a Lei de Imprensa, ela deve ser integralmente afastada do ordenamento jurídico.

A primeira a fazer uma análise dos artigos impugnados, a ministra Cármen Lúcia apontou de forma individualizada como os dispositivos afrontavam a atual Carta, inclusive muitos já tendo sido afastados quer por decisões do próprio STF, quer por decisões do Superior Tribunal de Justiça. Destacou, nessa linha, que a lei n. 5.250/67 tratava de forma diferenciada e

${ }^{34}$ BRASIL. Supremo Tribunal Federal. Tribunal Pleno. Acórdão da decisão do caso da Lei de Imprensa. ADPF 130. Relator: Ministro Carlos Britto. Julgado em: 30/04/2009, pp. 87 e ss. Publicado em: DJe-208 06/11/2009. Disponível em: http://redir.stf.jus.br/paginadorpub/paginador.jsp?docTP=AC\&docID=605411. Acesso em: 25 mar. 2019. 
ISSN 1981-3694

(DOI): $10.5902 / 1981369437843$

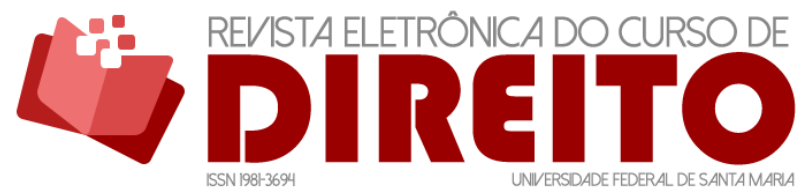

PROTEÇ̃̃O DOS PARTICULARES E CENSURA PRIVADA: A JURISPRUDÊNCIA CONSTITUCIONAL SOBRE OS LIMITES À LIBERDADE DE EXPRESSÃO

ELDEN BORGES SOUZA VICTOR SALES PINHEIRO

mais gravosa os atos veiculados pela imprensa, prejudicando o funcionamento dos meios de comunicação e o trabalho dos jornalistas.

Deixou claro, ainda, a ministra que a Lei de Imprensa tinha um teor verdadeiramente inquisitorial, cerceando a palavra e possibilitando o despotismo. $\mathrm{E}$ mais, destacou que a liberdade integra a dignidade humana, portanto uma restrição à primeira atinge a segunda ${ }^{35}$. Por fim, embora tenha reconhecido que é possível a edição de uma lei de imprensa, reconheceu que a lei n. 5.250/67, ao extinguir uma liberdade, não é válida constitucionalmente.

Em seu voto, Joaquim Barbosa reforçou a importância da liberdade de imprensa para a democracia, especialmente para democracias novas, como a brasileira. No entanto, para cumprir sua missão, a imprensa, além de livre, deve ser plural, servindo de meio de comunicação para os mais diversos segmentos da sociedade civil. Quando o Estado realiza tal inclusão, sua intervenção não é negativa. Sendo assim, o Estado pode deixar de ser opressor da liberdade de expressão para tornar-se fonte de liberdade.

Dessa forma, o ministro não considerou que a lei como um todo afrontava a Constituição de 1988. Votou por dar interpretação conforme aos artigos $1^{\circ}, \S 1^{\circ}, 2^{\circ}, 14$ e 16 , I da lei $n$. 5.250/67. Por sua vez, os artigos $1^{\circ}$, § $2^{\circ}, 3^{\circ}$ a $6^{\circ}$ e 65 seriam incompatíveis com o atual texto constitucional. Vale destacar que o ministro considerou constitucional o tratamento penal diferenciado voltado aos meios de comunicação social, em razão da maior intensidade do dano causado à imagem da pessoa ofendida (artigos 20, 21 e 22).

Cezar Peluso destacou que a Constituição tem a preocupação de manter o equilíbrio entre a liberdade de imprensa e a dignidade da pessoa humana. Votou pela declaração de não recepção integral da lei, pois se fosse declarada apenas dos dispositivos impugnados, os demais perderiam o sentido.

A seu turno, a ministra Ellen Gracie ressaltou que é admissível uma lei sobre a liberdade de imprensa para compatibilizar direitos colidentes ${ }^{36}$. Em que pese a imprensa deva ser necessariamente livre, não há hierarquia entre direitos fundamentais que afaste qualquer intervenção da liberdade de expressão. Assim, acompanhou a divergência iniciada pelo ministro Joaquim Barbosa.

Em sentido diametralmente oposto, Marco Aurélio não conheceu da ação. Na sua visão não havia violação a preceito fundamental, pois a imprensa não seria prejudicada pela referida

35 BRASIL. Supremo Tribunal Federal. Tribunal Pleno. Acórdão da decisão do caso da Lei de Imprensa. ADPF 130. Relator: Ministro Carlos Britto. Julgado em: 30/04/2009, pp. 97 e ss. Publicado em: DJe-208 06/11/2009. Disponível em: http://redir.stf.jus.br/paginadorpub/paginador.jsp?docTP=AC\&doclD=605411. Acesso em: 25 mar. 2019.

36 Ibidem, pp. 127 e ss. 
ISSN 1981-3694

(DOI): $10.5902 / 1981369437843$

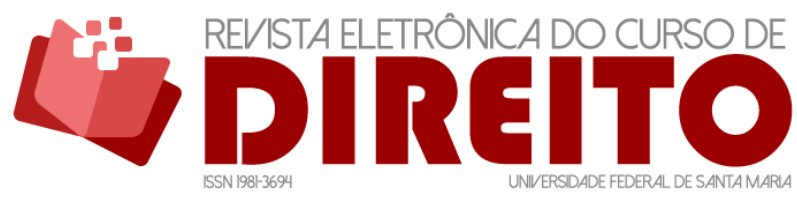

PROTEÇ̃̃O DOS PARTICULARES E CENSURA PRIVADA: A JURISPRUDÊNCIA CONSTITUCIONAL SOBRE OS LIMITES À LIBERDADE DE EXPRESSÃO

ELDEN BORGES SOUZA VICTOR SALES PINHEIRO

lei. A lei n. 5.250/67 já teria sido devidamente depurada pelo Judiciário após a promulgação da Constituição de 1988, dessa forma o vácuo normativo é que representaria um grande prejuízo para jornalistas e cidadãos.

Segundo o ministro, muitos assuntos dependem de regulamentação normativa, o que seria realizado pela lei de imprensa ${ }^{37}$. Aquilo que representava autoritarismo ditatorial já havia deixado de ser aplicado, o que restou da lei n. 5.250/67 seria a garantia de diversos direitos fundamentais, como a honra, vida privada e imagem. Assim, como a imprensa brasileira não deixava de ser livre pela existência dessa lei, a ADPF não deveria ter sido conhecida.

Celso de Mello, por sua vez, destacou inúmeros pontos na afirmação da não recepção da lei de imprensa. Destacou que a crítica, quando voltada ao interesse público, como a jornalística, merece especial proteção do Estado. Dessa forma, mesmo a crítica veemente, se ausente a intenção de injuriar, é tutelada constitucionalmente.

Citando decisões de outros países e de cortes internacionais, destacou que a liberdade de imprensa não se resume à reprodução objetiva de fatos, mas inclui o direito à crítica e à interpretação das informações ${ }^{38}$. A liberdade de expressão significa que o Estado não tem o poder para determinar convicções ou intervir em posições políticas, filosóficas, ideológicas ou confessionais. Afinal, o debate público deve ser amplo.

Restrições são possíveis, conforme expressamente prevê a Convenção Americana de Direitos Humanos, afinal a liberdade de expressão não permite a ofensa a outros valores constitucionais. Embora este direito proteja posições minoritárias e desagradáveis, não impede a incidência de tipos penais, que especificam um juízo de reprovação decorrente de uma ponderação legislativa.

Para finalizar, o ministro ainda destacou que a liberdade de expressão também tem eficácia contra particulares; porém, por outro lado, os direitos de personalidade configuram uma limitação externa àquele direito. Quanto ao direito de resposta, em que pese ser útil uma regulamentação legislativa, a Constituição pode ser aplicada diretamente. Portanto, a lei de imprensa como um todo deveria ser afastada.

${ }^{37}$ BRASIL. Supremo Tribunal Federal. Tribunal Pleno. Acórdão da decisão do caso da Lei de Imprensa. ADPF 130. Relator: Ministro Carlos Britto. Julgado em: 30/04/2009, pp. 140 e ss. Publicado em: DJe-208 06/11/2009. Disponível em: http://redir.stf.jus.br/paginadorpub/paginador.jsp?docTP=AC\&doclD=605411. Acesso em: 25 mar. 2019.

38 Ibidem, pp. 154 e ss. 
ISSN 1981-3694

(DOI): $10.5902 / 1981369437843$

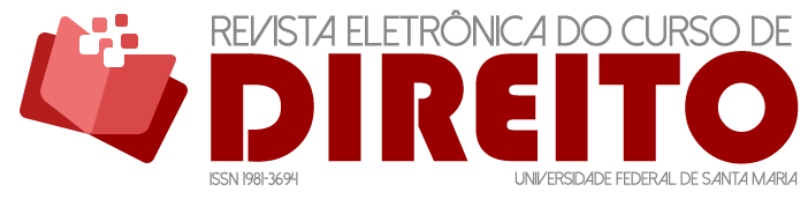

PROTEÇ̃̃O DOS PARTICULARES E CENSURA PRIVADA: A JURISPRUDÊNCIA CONSTITUCIONAL SOBRE OS LIMITES À LIBERDADE DE EXPRESSÃO

ELDEN BORGES SOUZA VICTOR SALES PINHEIRO

Último a votar, Gilmar Mendes ressaltou que a liberdade de imprensa é uma tarefa a ser cumprida, não basta sua previsão normativa ${ }^{39}$. Embora os textos constitucionais tendam a prever este direito como quase absoluto, com o passar do tempo houve a definição legislativa e jurisprudencial do seu conteúdo. Nesse sentido, é densa a posição dos tribunais dos Estados Unidos e da Alemanha.

Sustentou que nem toda lei sobre a liberdade de expressão é inconstitucional, pois uma lei nesse sentido pode servir à promoção desse direito ou à regulação de exceções. Com base na posição alemã, afirmou que a liberdade de imprensa enquanto direito subjetivo configura um direito de defesa contra a intervenção estatal; já enquanto direito objetivo implica o dever do Estado de assegurar o instituto da imprensa livre.

Quanto a uma lei de imprensa, o ministro destacou que a liberdade de imprensa constitui uma garantia institucional, portanto exige uma intervenção legislativa para a sua harmonização com outros valores fundamentais, afinal, não é absoluta. No entanto, tal atuação legislativa deve cumprir o expresso na Constituição, portanto trata-se de uma reserva legal qualificada. Nesse sentido, citou leis de imprensa de diversos países democráticos.

O problema da lei n. 5.250/67 é a tendência a institucionalizar a censura oficial e a intervenção do Estado. De caráter repressivo, essa lei vem sendo depurada pelos tribunais depois da Constituição de 1988, tornando-se uma garantia dos cidadãos contra os abusos da imprensa que violam os direitos individuais, como no caso da Escola Base. Trata-se de uma defesa da imprensa e contra a imprensa.

Concluindo, afirmou que o direito de resposta, consubstanciando essa garantia dos indivíduos em face do poder dos meios de comunicação, não pode ficar sem regulamentação infraconstitucional ${ }^{40}$. Deixar ao juízo do magistrado a aplicação do preceito constitucional causaria grande insegurança jurídica. Portanto, ressalvando o capítulo referente ao direito de resposta, a lei de imprensa deveria ser declarada como não recepcionada.

Dessa forma, vencidos os ministros Joaquim Barbosa, Ellen Gracie e Gilmar Mendes, apenas em parte, e o Ministro Marco Aurélio, na totalidade, o Supremo Tribunal declarou não recepcionada a integralidade da lei n. 5.250/67.

Esse caso é fundamental para a compreensão da relação entre o Estado e a imprensa, no entanto também é central para a relação entre os particulares e a imprensa. Podemos

39 BRASIL. Supremo Tribunal Federal. Tribunal Pleno. Acórdão da decisão do caso da Lei de Imprensa. ADPF 130. Relator: Ministro Carlos Britto. Julgado em: 30/04/2009, pp. 223 e ss. Publicado em: DJe-208 06/11/2009. Disponível em: http://redir.stf.jus.br/paginadorpub/paginador.jsp?docTP=AC\&docID=605411. Acesso em: 25 mar. 2019.

40 Ibidem, pp. 262 e ss. 
ISSN 1981-3694

(DOI): $10.5902 / 1981369437843$

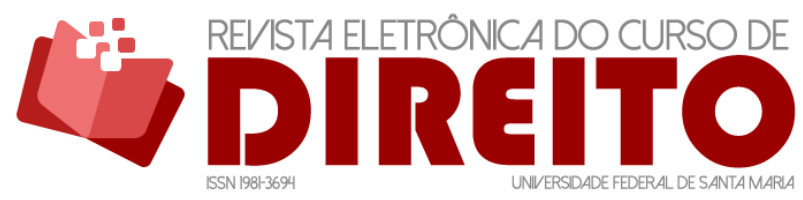

PROTEÇ̃̃ DOS PARTICULARES E CENSURA PRIVADA: A JURISPRUDÊNCIA CONSTITUCIONAL SOBRE OS LIMITES À LIBERDADE DE EXPRESSÃO

ELDEN BORGES SOUZA VICTOR SALES PINHEIRO

concluir que a imprensa possui direitos fundamentais no exercício de sua função inclusive contra agentes particulares, considerando um conceito extensivo de censura, que admite a existência de censura privada e veta-a. Por outro lado, esse direito implica obrigações, especialmente de garantia da verdade.

Se, por um lado, o direito de informar permite que os meios de comunicação não sejam embaraços por agentes privados; por outro lado, deve observar os direitos fundamentais das pessoas envolvidas em sua tarefa, sob pena de ser aplicado um outro direito fundamental reconhecido pelo Tribunal, o direito de resposta. A relação entre liberdade de imprensa e direito de resposta é uma clara demonstração de que as liberdades abrangidas pela liberdade de expressão têm uma preocupação central com as relações entre indivíduos e não somente na relação Estado-cidadão.

\section{O CASO DA MARCHA DA MACONHA E A PROTEÇÃO DO DISCURSO CRÍTICO AO DIREITO VIGENTE}

Outro caso relevante sobre o tema foi a ADPF $187^{41}$. Essa ação discutiu se a denominada “Marcha da Maconha", manifestação pública que propõe a descriminalização do uso da maconha, ao criticar a criminalização de um ato, estava protegida pela liberdade de pensamento ou se configuraria um crime de apologia de crime (art. 287 do Código Penal). Os ministros, por unanimidade, deram interpretação conforme ao Código Penal para excluir interpretações que criminalizassem esse movimento.

O Relator do processo, ministro Celso de Mello, discorreu de forma extensa sobre as liberdades de pensamento, reunião e manifestação. De início, tratou sobre o cabimento da ADPF, destacando que há uma controvérsia interpretativa que põe em risco uma liberdade fundamental, se tal interpretação do Código Penal for inadmissível. 0 ministro destacou que o direito de reunião é um instrumento de concretização da liberdade de expressão, sendo que a garantia dada por este direito contra a intervenção externa vem sendo constantemente afirmada pela jurisprudência do Supremo ${ }^{42}$.

\footnotetext{
41 BRASIL. Supremo Tribunal Federal. Tribunal Pleno. Acórdão da decisão do caso da marcha da maconha. ADPF 187. Relator: Min. Celso de Mello Julgado em 15/06/2011, Publicado em: 29/05/2014. Disponível em: http://redir.stf.jus.br/paginadorpub/paginador.jsp?docTP=TP\&doclD=5956195. Acesso em: 25 mar. 2019.

42 Ibidem, p. 19.
} 
ISSN 1981-3694

(DOI): $10.5902 / 1981369437843$

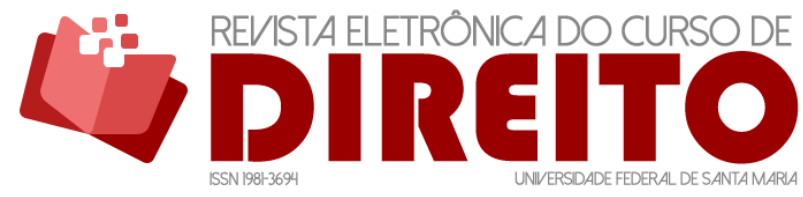

PROTEÇ̃̃O DOS PARTICULARES E CENSURA PRIVADA: A JURISPRUDÊNCIA CONSTITUCIONAL SOBRE OS LIMITES À LIBERDADE DE EXPRESSÃO

ELDEN BORGES SOUZA VICTOR SALES PINHEIRO

$\mathrm{Na}$ definição da liberdade de reunião, o ministro apontou cinco elementos conceituais: pluralidade de participantes, reunião transitória, finalidade comum, elemento espacial, área territorialmente delimitada e organização, embora precária, sendo imprescindível que seja pacífica e vedada utilização de armas. Destacou, ainda, que se parte portar armas ou não agir de forma pacífica, a polícia pode agir apenas em relação a estes, e não contra toda a reunião.

Por fim, destacou o caráter contramajoritário da liberdade de expressão em geral. Ressaltou que nem a maioria, nem o Estado podem cercear o pensamento minoritário, por mais desagradável que possa $\operatorname{ser}^{43}$. Este direito veda o controle da expressão e da reunião, no caso. Ora, discurso antagônico não merece repressão e sim tolerância, afinal a verdade nem sempre está com a maioria. Em razão do caráter transformador das ideias e do fato de que a Marcha da Maconha apenas defende o debate, o relator votou pela procedência da ação.

A seu turno, Luiz Fux destacou que em tais conflitos o Judiciário deve adotar uma posição minimalista, para não assumir uma posição de censura. A participação democrática das pessoas depende da autonomia individual, sendo a liberdade de expressão um dos aspectos dessa autonomia $^{44}$. Por isso, votou parcialmente procedente, condicionando a Marcha da Maconha ao cumprimento dos requisitos impostos pelo art. $5^{\circ}, \mathrm{XVI}, \mathrm{CRFB} / 88$, ao não consumo de drogas e, principalmente, se não estiverem presentes crianças e adolescentes. No entanto, após longo debate, concordou que suas ressalvas não afastavam em nada a procedência do pedido, dessa forma mudou seu voto para totalmente procedente.

Cármen Lúcia proferiu voto com foco na democracia e no pluralismo. Destacou que a democracia depende da justiça, no entanto a ideia de justiça apenas amadurece quando as pessoas podem discutir, por isso ela pode mudar de tempos em tempos. Já o pluralismo é defendido constitucionalmente desde o preâmbulo, e não há pluralidade sem contrários e sem diferentes. Lembrou, ainda, que não há democracia intolerante, pois ela pressupõe a existência de diversidade. Dessa forma, como a Marcha da Maconha apenas defende a discussão e não o consumo de drogas, votou pela procedência do pedido.

Por sua vez, Ricardo Lewandowski deu ênfase à liberdade de reunião como um direito instrumental para a efetivação da liberdade de expressão ${ }^{45}$. Consignou, ainda, que o conceito de

43 BRASIL. Supremo Tribunal Federal. Tribunal Pleno. Acórdão da decisão do caso da marcha da maconha. ADPF 187. Relator: Min. Celso de Mello Julgado em 15/06/2011, pp. 89 e ss. Publicado em: 29/05/2014 Disponível em: http://redir.stf.jus.br/paginadorpub/paginador.jsp?docTP=TP\&docID=5956195. Acesso em: 25 mar. 2019.

44 Ibidem, p. 139.

45 Ibidem, p. 166. 
ISSN 1981-3694

(DOI): $10.5902 / 1981369437843$

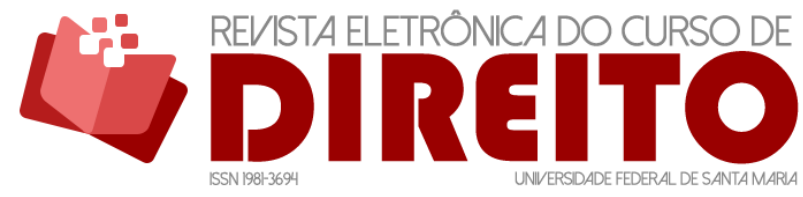

PROTEÇ̃̃O DOS PARTICULARES E CENSURA PRIVADA: A JURISPRUDÊNCIA CONSTITUCIONAL SOBRE OS LIMITES À LIBERDADE DE EXPRESSÃO

ELDEN BORGES SOUZA VICTOR SALES PINHEIRO

drogas não é absoluto, uniforme ou permanente. Trata-se de matéria controvertida; dessa forma, é importante seu debate. Portanto, seguiu o relator.

$\mathrm{Na}$ mesma linha, Ayres Britto também destacou a instrumentalidade da liberdade de reunião. Ressaltou, então, que eliminar o direito meio implica eliminar o direito fim, ou seja, a expressão do pensamento. A discussão é necessária para fortalecer o senso crítico e, assim, afastar pré-compreensões. Conforme o ministro, o pensamento crítico é libertador. Sem o debate, as normas jurídicas seriam perpétuas. Afirmando que é lícito discutir qualquer tema, mesmo sobre coisas ilícitas, acompanhou o relator.

Marco Aurélio notou que embora o conceito de moderno de democracia não seja idêntico ao da liberdade dos antigos, ele inclui a possibilidade de ir à público e emitir opiniões. Para tanto é indispensável a possibilidade de livremente expressar uma ideia. Com base na teoria comunicativa de Habermas, destacou que os direitos fundamentais são exatamente a garantia da abertura de espaços comunicativos e da possibilidade de participação geral, o que dá legitimidade às normas jurídicas ${ }^{46}$. 0 diálogo e a exposição dos mais diversos argumentos à crítica pública garante a correção das decisões.

Por fim, enfatizou a importância da liberdade de expressão para a autodeterminação e individualidade, pois quando o indivíduo expressa publicamente suas opiniões e pensamentos, se vale da liberdade para desenvolver sua personalidade. Concluindo, lembrou que a liberdade de expressão existe para tutelar opiniões incômodas e capazes de gerar reflexões e modificar opiniões, e não para proteger as posições agradáveis ou simplesmente indiferentes. Votou, então, pela procedência da ação.

Último a votar, Cezar Peluso destacou a liberdade de expressão como emanação da dignidade da pessoa humana e como fator de formação e aprimoramento da democracia. Neste aspecto, o debate aberto destinado ao convencimento é a melhor resposta e melhor forma de combate a ideias ou concepções. Em sua opinião, a exceção a esse direito ocorre unicamente quando for capaz de causar desordem social ou violar direitos alheios ${ }^{47}$. Acompanhou o relator.

Ressalte-se que não votaram os ministros Dias Toffoli, por estar impedido, Gilmar Mendes e Joaquim Barbosa, ambos ausentes justificadamente da sessão de julgamento. Dessa forma, em 15 de junho de 2011, o Supremo Tribunal, por unanimidade, rejeitou as preliminares

46 BRASIL. Supremo Tribunal Federal. Tribunal Pleno. Acórdão da decisão do caso da marcha da maconha. ADPF 187. Relator: Min. Celso de Mello Julgado em 15/06/2011, pp. 186 e ss. Publicado em: 29/05/2014. http://redir.stf.jus.br/paginadorpub/paginador.jsp?docTP=TP\&docID=5956195. Acesso em: 25 mar. 2019. 47 Ibidem, p. 96. 
ISSN 1981-3694

(DOI): $10.5902 / 1981369437843$

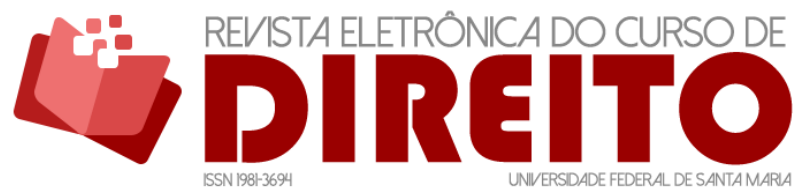

PROTEÇ̃̃ DOS PARTICULARES E CENSURA PRIVADA: A JURISPRUDÊNCIA CONSTITUCIONAL SOBRE OS LIMITES À LIBERDADE DE EXPRESSÃO

ELDEN BORGES SOUZA VICTOR SALES PINHEIRO

e, no mérito, deu ao art. 287, do Código Penal interpretação conforme à Constituição, excluindo de sua tipificação a marcha da maconha.

Este caso contribui para a elucidação da interpretação dada pelo Tribunal no Caso Ellwanger, em que as restrições à liberdade de expressão não ficaram claras. 0 entendimento da Corte na ADPF 187 é de que a limitação à liberdade de expressão se dá na ocorrência de um fato ilícito, como o racismo, no caso anterior, e não por alguma manifestação contrária à lei, de oposição à lei, no caso. Sendo que, por mais minoritária que seja a opinião, isso não justifica sua limitação. Ao contrário, em tais casos é que se torna mais necessária a proteção da liberdade de expressão do pensamento.

\section{O CASO DAS BIOGRAFIAS NÃO AUTORIZADAS E A PROTEÇÃO CONTRA A CENSURA PRIVADA}

Em 2012, a Associação Nacional dos Editores de Livros - ANEL, questionou perante o STF, através de Ação Declaratória de Inconstitucionalidade, a respeito da limitação sofrida na produção literária a partir da interpretação dos artigos 20 e 21 do Código Civil ${ }^{48}$. Pediu que fosse declarada a inconstitucionalidade parcial, sem redução de texto, para que, mediante interpretação conforme à Constituição, fosse afastada a necessidade do consentimento da pessoa biografada e das pessoas retratadas como coadjuvantes, ou de seus familiares, em caso de pessoas falecidas.

Segundo a ANEL, os dispositivos do CC/02 ferem a liberdade de expressão, configurando-se em verdadeira censura privada aos direitos de liberdade de pensamento, destoando do ordenamento constitucional brasileiro, uma vez que não há qualquer exceção na literalidade dos artigos, o que resulta na violação das liberdades fundamentais.

No julgamento, a Relatora, ministra Cármen Lúcia, fez um longo voto versando desde o ocorrido na audiência pública, bem como os parâmetros normativos constitucionais e as regras da interpretação demandada; a questão da liberdade de expressão, de pensamento de informação; direito à intimidade, à privacidade; conceituou o termo biografia e sua história e, por fim, interpretou os artigos a fim de eliminar colisão aparente e, assim, interpretou pela

${ }^{48}$ BRASIL. Supremo Tribunal Federal. Tribunal Pleno. Acórdão da decisão do caso das biografias não autorizadas. ADI 4815. Relatora para Acórdão: Ministra Cármen Lúcia. Julgado em: 10/06/2015. Publicado em: DJ 01/02/2016. Disponível em: http://redir.stf.jus.br/paginadorpub/paginador.jsp?docTP=TP\&docID=10162709. Acesso em: 25 mar. 2019. 
ISSN 1981-3694

(DOI): $10.5902 / 1981369437843$

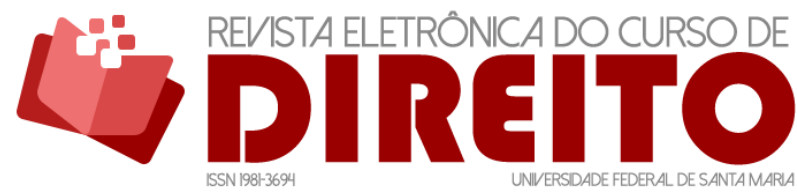

PROTEÇ̃̃O DOS PARTICULARES E CENSURA PRIVADA: A JURISPRUDÊNCIA CONSTITUCIONAL SOBRE OS LIMITES À LIBERDADE DE EXPRESSÃO

ELDEN BORGES SOUZA VICTOR SALES PINHEIRO

efetividade máxima das normas fundamentais, concluindo que é inexigível a autorização prévia para publicação de biografias.

A ministra enfatizou a liberdade de expressão como núcleo essencial à vivência humana, sendo garantido na Constituição da República e nos textos declaratórios de direitos humanos ${ }^{49}$. Porém, ressaltou que a garantia dada igualmente aos demais direitos fundamentais pode gerar potencial conflito. Nesse quesito, declarou que a técnica da ponderação dos valores demonstrou que os artigos 20 e 21 do Código Civil somente serão legitimamente válidos e subsistentes no sistema jurídico se for afastada qualquer limitação para a expressão literária ou audiovisual, ou seja, sua produção e limitação devem ser independentes de autorização prévia. Isso a Constituição da República garante.

Ressaltou também que os incisos IV, V, IX, X e XIV, do artigo $5^{\circ}$ e o artigo 200 da Constituição proíbem censura de qualquer natureza, bem como garantem a inviolabilidade da intimidade, da privacidade, da honra e da dignidade da pessoa humana. No entanto, declarou que as normas infraconstitucionais não podem cercear ou restringir direitos fundamentais constitucionais, sob pretexto de estabelecer formas de proteção.

Nesse sentido, votou pela procedência da ADI 4.815, dando interpretação aos artigos supramencionados, para que não haja necessidade de consentimento da pessoa biografada, bem como de pessoas retratadas como coadjuvantes, ou seus familiares, em caso de pessoas falecidas, em acordo com os direitos fundamentais à liberdade de expressão, de criação artística e produção científica. Reafirmou, por outro lado, a proteção do direito à inviolabilidade da intimidade, nos casos concretos em que se patenteie desobediência aos princípios fundamentais do sistema.

Seguiram a Relatora, de forma unânime, todos os ministros. Merece destaque, no entanto, o voto do ministro Luiz Roberto Barroso. O ministro ressaltou que o Código Civil, em seus artigos 20 e 21, ao proteger dos direitos de personalidade, acabou por preterir o direito de liberdade de expressão, produzindo assim uma ilegítima hierarquização de direitos, em favor daqueles e em desfavor destes ${ }^{50}$. Insistiu na importância da liberdade de expressão no contexto democrático, ressaltando o dever da Suprema Corte em protegê-la, por ser uma liberdade preferencial e não hierarquizada, razões que fazem dela, prima facie, prevalecer.

${ }^{49}$ BRASIL. Supremo Tribunal Federal. Tribunal Pleno. Acórdão da decisão do caso das biografias não autorizadas. ADI 4815. Relatora para Acórdão: Ministra Cármen Lúcia. Julgado em: 10/06/2015, pp. 20 e ss. Publicado em: DJ 01/02/2016. Disponível em: http://redir.stf.jus.br/paginadorpub/paginador.jsp?docTP=TP\&doclD=10162709. Acesso em: 25 mar. 2019.

50 Ibidem, p. 144. 
ISSN 1981-3694

(DOI): $10.5902 / 1981369437843$

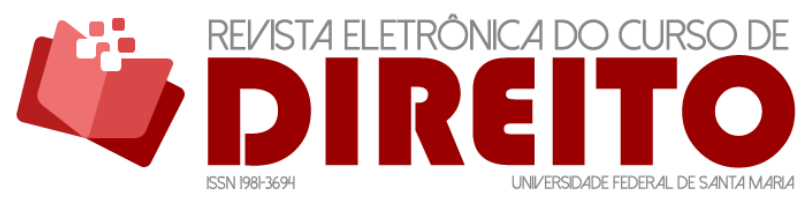

PROTEÇ̃̃ DOS PARTICULARES E CENSURA PRIVADA: A JURISPRUDÊNCIA CONSTITUCIONAL SOBRE OS LIMITES À LIBERDADE DE EXPRESSÃO

ELDEN BORGES SOUZA VICTOR SALES PINHEIRO

Versou também sobre o repúdio à censura, que tornou sofrida a história da liberdade de expressão e acidentou a nossa história. Apresentou também a fundamentação da liberdade como meio de exercer demais direitos, bem com sua relevância para o conhecimento da própria história e avanço da sociedade em geral. Por isso a necessidade deste direito ser afirmado e reafirmado, afastando toda e qualquer hipótese de censura prévia. Porém, resguardando os mecanismos a posteriori, que são: retratação, retificação, direito de resposta, indenização e eventualmente, a responsabilidade penal ${ }^{51}$.

Num todo, a Corte reforçou o discurso de que a necessidade de autorização prévia para biografias traduz-se em censura, o que seria uma tentativa de apagar ou controlar a história, o que não é compatível com um Estado Democrático de Direito. Também destacou as pessoas públicas e a sua natural exposição geradora do interesse público a seu respeito. Mas sempre relembrando das limitações aos abusos da liberdade de expressão.

Esse caso coroa a jurisprudência do Tribunal sobre a liberdade de expressão em casos particulares. O STF confirmou a aplicação da liberdade de expressão como garantia em face de particulares que, como base em outros interesses, pretendem cercear a difusão de alguma informação ou a manifestação de alguma opinião, caracterizando esse gesto como um tipo de censura privada. Ao mesmo tempo, confirmou que a aplicação da liberdade de expressão nesses casos não a torna isenta de observância dos demais direitos fundamentais, reconhecendo, portanto, uma dupla aplicação de direitos fundamentais.

\section{UMA ANÁLISE TRANSVERSAL DA JURISPRUDÊNCIA}

Diversos pontos foram reiteradamente sustentados pela maioria dos ministros, consolidando a opinião do Tribunal sobre tópicos da liberdade de pensamento. Entre tais pontos, é possível destacar uma opinião do Tribunal acerca do próprio conceito do direito em questão, de sua relação com a democracia, de sua contribuição para a formação da verdade e da vedação à censura. Portanto, será aqui demonstrado as linhas gerais dos principais aspectos pacificamente aceitos ao longo dos julgamentos apresentados.

51 BRASIL. Supremo Tribunal Federal. Tribunal Pleno. Acórdão da decisão do caso das biografias não autorizadas. ADI 4815. Relatora para Acórdão: Ministra Cármen Lúcia. Julgado em: 10/06/2015, p. 148. Publicado em: DJ 01/02/2016. Disponível em: http://redir.stf.jus.br/paginadorpub/paginador.jsp?docTP=TP\&docID=10162709. Acesso em: 25 mar. 2019. 
ISSN 1981-3694

(DOI): $10.5902 / 1981369437843$

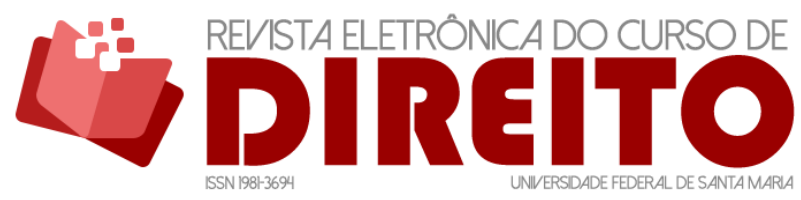

PROTEÇ̃̃O DOS PARTICULARES E CENSURA PRIVADA: A JURISPRUDÊNCIA CONSTITUCIONAL SOBRE OS LIMITES À LIBERDADE DE EXPRESSÃO

ELDEN BORGES SOUZA VICTOR SALES PINHEIRO

No primeiro aspecto, quanto à sua conceituação, percebe-se que a decisão no caso Ellwanger é a mais árida nesse aspecto ${ }^{52}$. Porém, nos casos seguintes, a posição dos membros da Corte é mais consolidada, auxiliando até na melhor compreensão não apenas da liberdade de pensamento, mas igualmente das liberdades de reunião e imprensa.

A exemplo, Marco Aurélio resume de forma adequada o entendimento da Corte quando resgata na Constituição de 1988 as bases de uma sociedade democrática e pluralista ${ }^{53}$. Dessa forma, a liberdade de pensamento, dentro da sistemática dos direitos fundamentais consagrados, assegura o direito ao discurso, a ter e expressar uma opinião, o direito de imprensa, à informação e o direito à proibição da censura. Este direito assegura a todos que suas opiniões, ainda que diversas, opostas, radicais ou absurdas, possam ser manifestadas livremente e contra a posição do Estado e da sociedade, ou seja, dos particulares, permitindo a formação do pensamento da comunidade.

Já o segundo maior consenso que foi possível destacar nas decisões analisadas, foi a relação entre a liberdade de pensamento, expressão e imprensa e a democracia. Os ministros ao longo de todo esse período sempre realçaram a liberdade de expressão do pensamento como meio indispensável para a construção de um espaço público de debate e para a participação de todos na tomada de decisões que afetem o Estado.

Tal entendimento é perceptível na fala do ministro Marco Aurélio, no julgamento da Marcha da Maconha, ao declarar que a liberdade de expressão ultrapassa uma dimensão estritamente individual, havendo uma dimensão social, pois se trata de princípio que efetiva a democracia ${ }^{54}$. Limitar a liberdade de expressão pode significar, então, limitar a própria democracia. Os indivíduos têm o direito de receber o maior número de informações possíveis, para desenvolver plenamente suas potencialidades e sua cidadania.

Compactuando do mesmo pensamento, a ministra Rosa Weber, no caso das biografias não autorizadas, conclui que a regra de um Estado Democrático de Direito é a liberdade de

\footnotetext{
52 BRASIL. Supremo Tribunal Federal. Tribunal Pleno. Acórdão da decisão do caso Ellwanger. HC 82424-2. Relator para Acórdão: Ministro Maurício Corrêa. Julgado em: 17/09/2003. Publicado em: DJ 19/03/2004. Disponível em: http://redir.stf.jus.br/paginadorpub/paginador.jsp?docTP=AC\&doclD=79052. Acesso em: 25 mar. 2019.

53 Ibidem, pp. 343 e ss.

${ }^{54}$ BRASIL. Supremo Tribunal Federal. Tribunal Pleno. Acórdão da decisão do caso da marcha da maconha. ADPF 187. Relator: Min. Celso de Mello Julgado em 15/06/2011, pp. 186 e ss. Publicado em: 29/05/2014. Disponível em: http://redir.stf.jus.br/paginadorpub/paginador.jsp?docTP=TP\&docID=5956195. Acesso em: 25 mar. 2019.
} 
ISSN 1981-3694

(DOI): $10.5902 / 1981369437843$

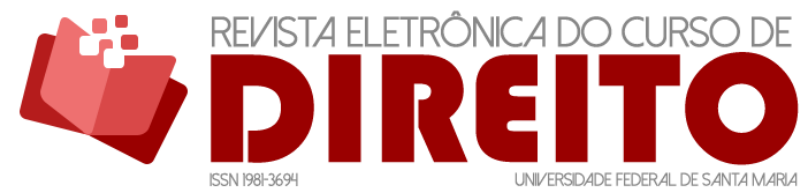

PROTEÇ̃̃O DOS PARTICULARES E CENSURA PRIVADA: A JURISPRUDÊNCIA CONSTITUCIONAL SOBRE OS LIMITES À LIBERDADE DE EXPRESSÃO

ELDEN BORGES SOUZA VICTOR SALES PINHEIRO

expressão, onde se admite "a sua restrição somente em situações excepcionais e nos termos da lei que, em qualquer caso, deverá observar os limites materiais emanados da Constituição"55.

Sobre o terceiro entendimento pacificado no Tribunal, é sobre a contribuição da liberdade de expressão para a formação da verdade, uma vez que a noção de que não há uma verdade absoluta nem posta objetivamente no mundo é uma constante nos julgamentos analisados. Não há um dono da verdade ou uma ideia infalível que se torne uma verdade eterna. A verdade seria formada por meio da discussão. Nesse contexto, muitos ministros destacaram como a liberdade de pensamento propicia a instauração do debate e, assim, a formação da verdade. Nesse aspecto, merece destaque a liberdade de imprensa, uma vez que a sua função é de emancipar mentes e espíritos através da disseminação do senso crítico, possibilitando o pluralismo, fundamento das sociedades autenticamente democráticas ${ }^{56}$.

Desta forma, é possível observar que na visão do Supremo Tribunal Federal a liberdade de expressão funciona como mecanismo de exposição de todas as posições à análise crítica e, dessa forma, meio de alcançar uma resposta. A verdade, nesse sentido, é resultado de um processo discursivo de confronto entre as várias teses existentes, processo que somente existe se houver ampla proteção às opiniões.

Por fim, e como consequência das posições expostas, o Tribunal possui algumas linhas de interpretação sobre a censura. Pode-se perceber que a discussão entre forma e conteúdo é importante, pois a censura é uma vedação que recai sobre a substância da expressão. Por outro lado, a forma acaba sendo a grande responsável pelos abusos, uso prejudicial a outras pessoas, da liberdade de pensamento. Carlos Velloso, por exemplo, votou que a manifestação de Ellwanger era panfletária e não científica e, por isso, merecia a reprimenda estatal ${ }^{57}$. Ou seja, a restrição se deu em razão da forma como sua posição foi veiculada e não em razão de sua posição em si.

\footnotetext{
55 BRASIL. Supremo Tribunal Federal. Tribunal Pleno. Acórdão da decisão do caso das biografias não autorizadas. ADI 4815. Relatora para Acórdão: Ministra Cármen Lúcia. Julgado em: 10/06/2015, p. 188. Publicado em: DJ 01/02/2016. Disponível em: http: / /redir.stf.jus.br/paginadorpub/paginador.jsp?docTP=TP\&docID=10162709. Acesso em: 25 mar. 2019. ${ }_{56}$ BRASIL. Supremo Tribunal Federal. Tribunal Pleno. Acórdão da decisão do caso da Lei de Imprensa. ADPF 130. Relator: Ministro Carlos Britto. Julgado em: 30/04/2009, p. 52. Publicado em: DJe-208 06/11/2009. Disponível em: http://redir.stf.jus.br/paginadorpub/paginador.jsp?docTP=AC\&docID=605411. Acesso em: 25 mar. 2019.

${ }^{57}$ BRASIL. Supremo Tribunal Federal. Tribunal Pleno. Acórdão da decisão do caso Ellwanger. HC 82424-2. Relator para Acórdão: Ministro Maurício Corrêa. Julgado em: 17/09/2003, p. 432. Publicado em: DJ 19/03/2004. Disponível em: http://redir.stf.jus.br/paginadorpub/paginador.jsp?docTP=AC\&doclD=79052. Acesso em: 25 mar. 2019.
} 
ISSN 1981-3694

(DOI): $10.5902 / 1981369437843$

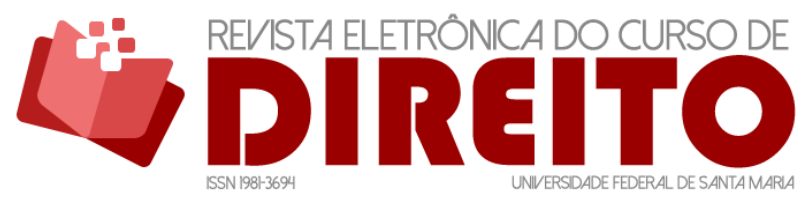

PROTEÇ̃̃O DOS PARTICULARES E CENSURA PRIVADA: A JURISPRUDÊNCIA CONSTITUCIONAL SOBRE OS LIMITES À LIBERDADE DE EXPRESSÃO

Marco Aurélio destacou que a censura do conteúdo sempre foi um instrumento poderoso em regimes totalitários. Assim, "a única restrição possível à liberdade de manifestação do pensamento, de modo justificado, é quanto à forma de expressão" ${ }^{58}$. Após enfatizar que a liberdade de expressão não é um direito absoluto, afirmou que o sistema constitucional brasileiro não agasalha certas formas de divulgação do pensamento, especificamente manifestação que seja "exacerbadamente agressiva, fisicamente contundente ou que exponha as pessoas a situações de risco iminente" ${ }^{59}$.

Por isso, os particulares apenas podem legitimamente requerer a proibição de uma manifestação ou a responsabilização de seu emissor caso haja uma violação de outro direito fundamental e não apenas pela exposição de fatos sobre a sua vida ${ }^{60}$. No caso das biografias não autorizadas, o Supremo Tribunal ampliou essa compreensão da censura trazida pelo Caso Ellwanger para compreender restritivamente as formas pelas quais a liberdade de expressão pode causar um dano passível de autorizar sua limitação.

Desta forma, a Corte entendeu pelo critério da restrição a partir da forma que a liberdade está sendo exercida ${ }^{61}$ quando atenta contra outros direitos ou valores constitucionalmente tutelados $^{62}$. E não em relação ao seu conteúdo, como no caso da Marcha da Maconha que visa defender uma ideologia. E como explica o ministro Marco Aurélio, por mais que as ideias causem repúdio, defender uma ideologia não é crime ${ }^{63}$.

Vale ressaltar também que esteve presente nos julgados apresentados, a preocupação dos ministros em enfatizar que a liberdade de expressão, embora se mostre como uma liberdade preferencial $^{64}$, nas palavras do ministro Roberto Barroso, não é absoluta nem incondicionada,

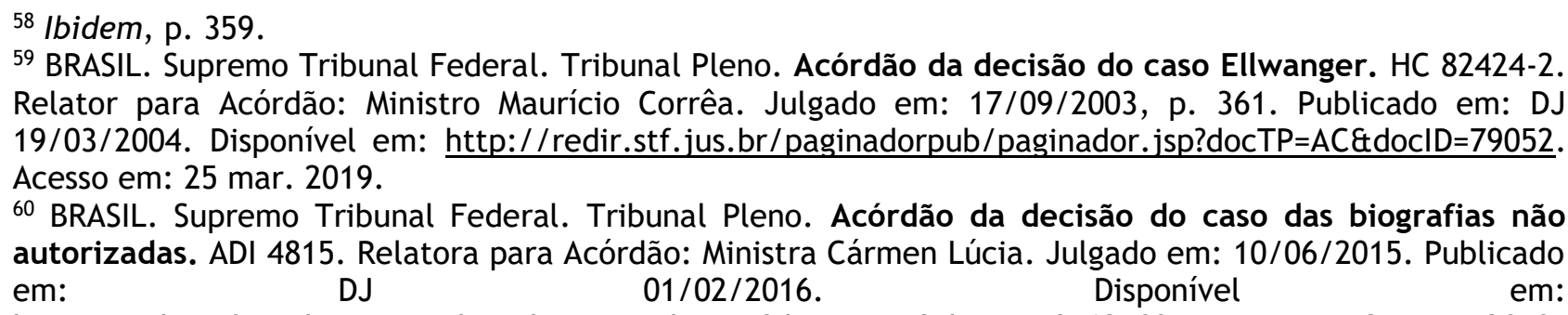
http://redir.stf.jus.br/paginadorpub/paginador.jsp?docTP=TP\&docID=10162709. Acesso em: 25 mar. 2019. ${ }^{61}$ BRASIL. Supremo Tribunal Federal. Tribunal Pleno. Acórdão da decisão do caso Ellwanger. HC 82424-2. Relator para Acórdão: Ministro Maurício Corrêa. Julgado em: 17/09/2003, p. 317. Publicado em: DJ 19/03/2004. Disponível em: http://redir.stf.jus.br/paginadorpub/paginador.jsp?docTP=AC\&doclD=79052. Acesso em: 25 mar. 2019.

62 BRASIL. Supremo Tribunal Federal. Tribunal Pleno. Acórdão da decisão do caso das biografias não autorizadas. ADI 4815. Relatora para Acórdão: Ministra Cármen Lúcia. Julgado em: 10/06/2015. Publicado em: DJ 01/02/2016. Disponível em: http: //redir.stf.jus.br/paginadorpub/paginador.jsp?docTP=TP\&docID=10162709. Acesso em: 25 mar. 2019. 63 Ibidem, p. 364.

64 Ibidem, p. 144. 
ISSN 1981-3694

(DOI): $10.5902 / 1981369437843$

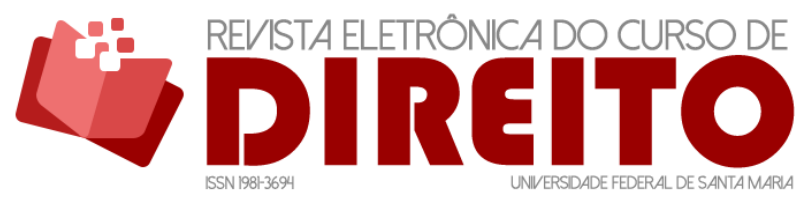

PROTEÇ̃̃ DOS PARTICULARES E CENSURA PRIVADA: A JURISPRUDÊNCIA CONSTITUCIONAL SOBRE OS LIMITES À LIBERDADE DE EXPRESSÃO

ELDEN BORGES SOUZA VICTOR SALES PINHEIRO

assim como os demais direitos fundamentais. Desta forma, a colisão entre eles não possui uma solução prévia, a primazia por um dos direitos em conflito deve se dar conforme a ponderação do caso concreto. Ou seja, endossando a já exposta teoria do suporte fático amplo sobre os direitos fundamentais, especialmente sobre a liberdade de expressão.

\section{CONCLUSÃO}

É interessante observarmos que a aplicação dos direitos fundamentais às relações particulares na Alemanha (Drittwirkung) começou exatamente por um caso envolvendo a liberdade de expressão e a tentativa de limitação com base nos direitos de personalidade, o já citado caso Lüth. A partir de então, a doutrina começou a desenvolver uma sistemática sobre a forma e as hipóteses de aplicação de direitos fundamentais em face de terceiros, considerando que a relação típica desses direitos seria Estado-cidadão ${ }^{65}$.

Nesse sentido, o presente trabalho buscou desenvolver as linhas gerais que definem a posição da Corte sobre a liberdade de expressão e sua aplicação e limites em relações entre particulares, de forma a poder apresentar soluções para casos futuros. Afinal, sem uma compreensão sistematizada acerca da posição do Tribunal não é possível firmar uma linha de princípio de sua jurisprudência. Considerando que no âmbito privado a proibição da manifestação do pensamento também pode configurar um tipo de censura, a correta definição dos limites é fundamental para um ambiente verdadeiramente democrático.

Analisando as decisões expostas é identificada, embora com algumas dificuldades, uma linha de princípio. Em que pese os ministros possuam visões diferentes acerca de tais aspectos, tais diversidades não eliminam a convergência conceitual. Inclusive, tendo em vista que o Supremo Tribunal Federal vem se configurando como um tribunal de teses jurídicas, a partir da jurisprudência indicada poderia ser formulada a seguinte tese: "é passível de configurar censura inconstitucional a decisão judicial que, pretendendo preservar interesses particulares, restringe excessivamente a liberdade de expressão (art. $5^{\circ}$, IV, CRFB/88) de uma das partes".

Portanto, o presente trabalho apontou os marcos conceituais que podem ser úteis para compreensão da posição atual do Tribunal, bem como solução de outros conflitos postos. A título exemplificativo, uma conclusão passível de se extrair da posição doutrinária e jurisprudencial acerca do assunto é a inconstitucionalidade, na verdade não recepção, do art. 35 da lei n.

${ }^{65}$ SARMENTO, Daniel. Direitos fundamentais e relações privadas. Rio de Janeiro: Lumens Juris, 2004, pp. 11 e sS. 
ISSN 1981-3694

(DOI): $10.5902 / 1981369437843$

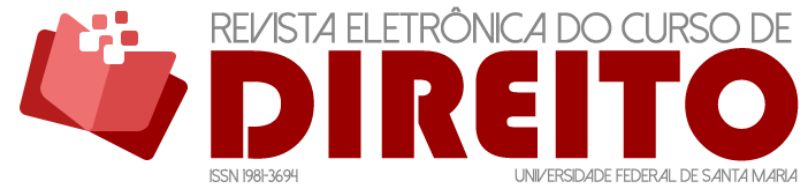

PROTEÇ̃̃O DOS PARTICULARES E CENSURA PRIVADA: A JURISPRUDÊNCIA CONSTITUCIONAL SOBRE OS LIMITES À LIBERDADE DE EXPRESSÃO

ELDEN BORGES SOUZA VICTOR SALES PINHEIRO

5.700/71. Esta lei, exemplo da legislação elaborada pela Ditadura Militar, ao tratar dos símbolos nacionais, define como contravenção penal violar os símbolos nacionais.

Como exposto, a manifestação de uma ideia pode incluir até mesmo a destruição de um símbolo nacional, como forma de chamar a atenção, de divulgar de forma mais eficaz uma opinião. Tal ato pode ser uma forma de expressão indesejável ou ofensiva à maioria da sociedade. No entanto, por todos os conceitos apresentados, trata-se de conduta inevitavelmente tutelada por tais liberdades. Sendo assim, tal dispositivo cerceia completamente tal possibilidade, não mais se coadunando com a Constituição vigente.

Afinal, a liberdade de expressão não é um direito acessório. Tal direito é a consagração de uma sociedade formada por seres racionais e sociais, que além de terem a capacidade de formar opiniões, também desejam compartilhá-las com os seus semelhantes. Nesse sentido, tal direito resguarda principalmente opiniões que são seriam bem recebidas, garantindo um direito de defesa contra o Estado, contra grupos majoritários, ainda que formado por pessoas particulares, e contra indivíduos que tenham um interesse oposto.

A Corte, por todo exposto no presente trabalho, vem afirmando e reafirmando a importância deste direito. Comprometido com o avanço democrático do país e com o pleno desenvolvimento da personalidade, o Tribunal é pacífico em seu entendimento de que a liberdade de expressão tem um potencial transformador, individual e coletivo, devendo ser protegido de instituições públicas, mas também de agentes privados.

\section{REFERÊNCIAS}

BASTOS, Celso Ribeiro. Hermenêutica e Interpretação Constitucional. 2. ed. São Paulo: IBDC, 1999.

BRASIL. Supremo Tribunal Federal. Tribunal Pleno. Acórdão da decisão do caso da manifestação na Praça dos Três Poderes. ADI 1969. Relator: Min. Ricardo Lewandowski. Julgado em: 28/06/2007. Publicado em: DJ 31/08/2007. Disponível em: http: //redir.stf.jus.br/paginadorpub/paginador.jsp?docTP=AC\&doclD=484308. Acesso em: 25 mar. 2019.

BRASIL. Supremo Tribunal Federal. Tribunal Pleno. Acórdão da decisão do caso das biografias não autorizadas. ADI 4815. Relatora para Acórdão: Ministra Cármen Lúcia. Julgado em: 10/06/2015. Publicado em: DJ 01/02/2016. Disponível em: http: //redir.stf.jus.br/paginadorpub/paginador.jsp?docTP=TP\&docID=10162709. Acesso em: 25 mar. 2019.

BRASIL. Supremo Tribunal Federal. Tribunal Pleno. Acórdão da decisão do caso da Lei de Imprensa. ADPF 130. Relator: Ministro Carlos Britto. Julgado em: 30/04/2009. Publicado em: 
ISSN 1981-3694

(DOI): $10.5902 / 1981369437843$

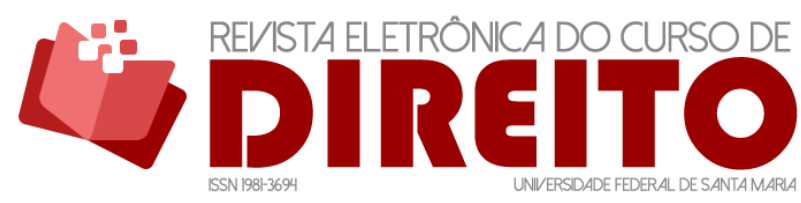

PROTEÇ̃̃O DOS PARTICULARES E CENSURA PRIVADA: A JURISPRUDÊNCIA CONSTITUCIONAL SOBRE OS LIMITES À LIBERDADE DE EXPRESSÃO

ELDEN BORGES SOUZA VICTOR SALES PINHEIRO

DJe-208 06/11/2009. Disponível em:

http: //redir.stf.jus.br/paginadorpub/paginador.jsp?docTP=AC\&docID=605411. Acesso em: 25 mar. 2019.

BRASIL. Supremo Tribunal Federal. Tribunal Pleno. Acórdão da decisão do caso da marcha da maconha. ADPF 187. Relator: Min. Celso de Mello Julgado em 15/06/2011, Publicado em: 29/05/2014. Disponível em:

http: //redir.stf.jus.br/paginadorpub/paginador.jsp?docTP=TP\&docID=5956195. Acesso em: 25 mar. 2019.

BRASIL. Supremo Tribunal Federal. Tribunal Pleno. Acórdão da decisão do caso Ellwanger. HC 82424-2. Relator para Acórdão: Ministro Maurício Corrêa. Julgado em: 17/09/2003. Publicado em: DJ 19/03/2004. Disponível em:

http: //redir.stf.jus.br/paginadorpub/paginador.jsp?docTP=AC\&docID=79052. Acesso em: 25 mar. 2019.

COMPARATO, Fábio Konder. A Afirmação Histórica dos Direitos Humanos. 5. ed. São Paulo: Saraiva, 2007.

DIMOULIS, Dimitri; MARTINS, Leonardo. Teoria Geral dos Direitos Fundamentais. 2. ed. São Paulo: Editora Revista dos Tribunais, 2009.

FARIAS, Edilsom Pereira de. Colisão de direitos: a honra, a intimidade, a vida privada e a imagem versus a liberdade de expressão e informação. 2. ed. Porto Alegre: Sergio Antonio Fabris Editor, 2000.

JABUR, Gilberto Haddad. Liberdade de Pensamento e Direito à Vida Privada. São Paulo: Revista dos Tribunais, 2000.

MEYER-PFLUG, Samantha Ribeiro. Liberdade de expressão e discurso do ódio. São Paulo: Revista dos Tribunais, 2009.

MILL, John Stuart. Sobre a liberdade. São Paulo: Saraiva, 2011.

SARLET, Ingo Wolfgang. A Eficácia dos Direitos Fundamentais. 10. ed. Porto Alegre: Livraria do Advogado Editora, 2010.

SARMENTO, Daniel. Direitos fundamentais e relações privadas. Rio de Janeiro: Lumens Juris, 2004.

SCHWAB, Jürgen. Cinquenta anos de Jurisprudência do Tribunal Constitucional Alemão. Montevidéu: Fundação Konrad Adenauer Stiftung, 2006.

SILVA, Virgílio Afonso da. O conteúdo essencial dos direitos fundamentais e a eficácia das normas constitucionais. Revista de Direito do Estado, v. 4, pp. 23-51, 2006.

STROPPA, Tatiana; ROTHENBURG, Walter Claudius. Liberdade de expressão e discurso do ódio: o conflito discursivo nas redes sociais. Revista Eletrônica do Curso de Direito da UFSM, Santa Maria, RS, v. 10, n. 2, p. 450-468, dez. 2015. ISSN 1981-3694. Disponível em: 
https://periodicos.ufsm.br/revistadireito/article/view/19463. Acesso em: 25 abr. 2019. doi: http://dx.doi.org/10.5902/1981369419463.

TOLLER, Fernando M. O Formalismo na Liberdade de Expressão. São Paulo: Saraiva, 2010

VARELA, Alfredo. Direito Constitucional Brasileiro. Brasília: Senado Federal, 2002.

VILLEY, Michel. O Direito e os Direitos Humanos. São Paulo: WMF Martins Fontes, 2007.

Recebido em: 25.04.2019 / Revisões requeridas em: 30.03.2020 / Aprovado em: 09.04.2020 / Publicado em: 05.06.2020

\section{COMO FAZER REFERÊNCIA AO ARTIGO (ABNT):}

SOUZA, Elden Borges. PINHEIRO, Victor Sales. Proteção dos particulares e censura privada: A jurisprudência constitucional sobre os limites à liberdade de expressão. Revista Eletrônica do Curso de Direito da UFSM, Santa Maria, RS, v. 15, n. 1, e37843, jan./abr. 2020. ISSN 1981-3694. DOI:

http://dx.doi.org/10.5902/1981369437843. Disponível em:

https://periodicos.ufsm.br/revistadireito/article/view/37843 Acesso em: dia mês. ano.

Direitos autorais 2020 Revista Eletrônica do Curso de Direito da UFSM

Editores responsáveis: Rafael Santos de Oliveira e Angela Araujo da Silveira Espindola

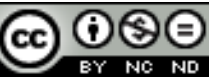

Esta obra está licenciada com uma Licença Creative Commons Atribuição-NãoComercial-SemDerivações 4.0 Internacional.

\section{SOBRE OS AUTORES}

ELDEN BORGES SOUZA

Doutorando em Direito pela Universidade Federal do Pará na linha Constitucionalismo, Democracia e Direitos Humanos. Mestre em Direito pela Universidade Federal do Pará, com área de concentração em Direitos Humanos. Aprovado com distinção pela banca examinadora. Professor universitário na Faculdade FACI-Wyden e no Centro Universitário FIBRA. Foi professor substituto na Universidade Federal do Pará de 2017 a 2019. Advogado. Atualmente integra o grupo de pesquisa Tradição da Lei Natural. Bacharel em Direito pelo Centro Universitário do Estado Pará (CESUPA). Segundo melhor discente concluinte do seu ano. Integrou, na Graduação, a Clínica de Direitos Humanos do CESUPA, por meio da qual participou de atividades de pesquisa sobre o Sistema Interamericano de Direitos Humanos e, também, participou de diversas simulações de julgamento perante tribunais internacionais. Obteve o prêmio de melhor orador da final e de toda a simulação, em Bogotá, no III Concurso Interamericano de Direito ao Desenvolvimento Sustentável. Integrou o grupo de pesquisa Direitos Fundamentais, Constituição e uso da Técnica da Ponderação como solução racional dos chamados casos difíceis. Cursou até o $4^{\circ}$ semestre de Ciências Contábeis na Universidade Federal do Pará (UFPA). Atualmente pesquisa a relação entre autoridade legal e direitos humanos.

\section{VICTOR SALES PINHEIRO}

Professor Adjunto da Universidade Federal do Pará (UFPA) e do Centro Universitário do Pará (CESUPA), na graduação e pósgraduação. Coordenador dos Grupos de Pesquisa (CNPq) "Tradição da Lei Natural" e .Razão pública, secularização e direitos humanos: casos, princípios e teorias políticas, e vice-coordenador do Grupo AdmEthics - Ética, Virtudes e Dilemas Morais na Administração. Doutor em Filosofia pela UERJ (Tese sobre Heidegger e Platão). Mestre em Filosofia pela PUC-RIO (Dissertação sobre a República de Platão). Graduado em Direito no Centro Universitário do Pará. Entre 2006 e 2010, coordenou as atividades do filósofo e crítico literário Benedito Nunes no Centro de Cultura e Formação Cristã (CCFC) em Belém, Pará. De Benedito Nunes, organizou e apresentou os seguintes livros: "A clave do poético" (Cia das Letras - Prêmio Jabuti de Teoria e 
ISSN 1981-3694

(DOI): $10.5902 / 1981369437843$

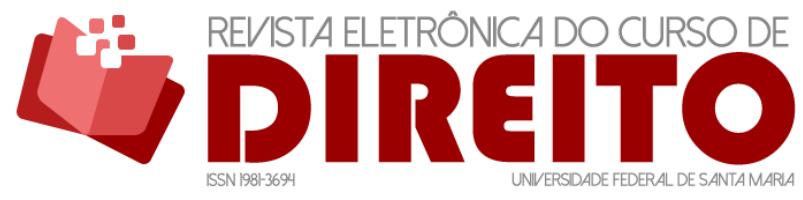

PROTEC̄̃O DOS PARTICULARES E CENSURA PRIVADA: A JURISPRUDÊNCIA CONSTITUCIONAL SOBRE OS LIMITES À LIBERDADE DE EXPRESSÃO

ELDEN BORGES SOUZA VICTOR SALES PINHEIRO

Crítica Literária 2011), "Ensaios Filosóficos" (Martins Fontes), "Do Marajó ao arquivo: breve panorama da cultura no Pará" (Ed.Ufpa/Secult-Pa), "A Rosa o que é de Rosa - Literatura e Filosofia" (Difel), "Heidegger" (Loyola). É organizador, junto com Luiz Costa Lima, do livro "Benedito Nunes - o pensamento poético" (Azougue Editorial) e, junto com Célia Jacob, da Revista Asas da Palavra n.25, edição em homenagem a Benedito Nunes (Ed.UNAMA - Universidade da Amazônia). Prestou consultoria para os seguintes documentários: "Benedito Nunes - um filósofo nos trópicos" (23 min.; direção Adalberto Müller; Nova Filmes) e "Mora na filosofia" (58 min.; direção Júnior Braga; Tv Cultura Pará). Publicou o ensaio "O deserto e as raízes: notas para uma crítica da crise da cultura" no livro "As cidades, as culturas e seus desafios: o CCFC na Amazônia" (ED.USC/CCFC). Junto com Benedito Nunes, é coordenador da edição bilíngue da obra completa de Platão, traduzida por Carlos Alberto Nunes, em 18 volumes (Ed.Ufpa - no prelo; vols. 1. Banquete, 2. Fedón, 3. Fedro, 4. República, 5. Apologia de SócratesCríton 6. Laques-Eutífron, 7. Cármides-Lísis, 8. Primeiro Alcibíades-Segundo Alcibíades e 9. Hípias Maior e Menor já publicados), para a qual escreveu o prefácio e a introdução ao Banquete. Áreas de interesse: Filosofia Moral, Política e Jurídica. Filosofia Clássica e Cristã. Teoria Neoclássica da Lei Natural. Secularização e liberdade religiosa. John Finnis. A. Maclntyre. C. Taylor. Em novembro de 2016, recebeu o Prêmio Edson Luis de Excelência Acadêmica, por eleição dos estudantes da Faculdade de Direito da UFPA. Site de cursos, palestras, artigos e edições: www.dialetico.com.br. 